\title{
Empirical Evidence of Changing Food Demand and Consumer Preferences in Russia
}

\author{
Vardges Hovhannisyan $^{1 \star \star}$ (D), Magdana Kondaridze ${ }^{1}$, Christopher Bastian ${ }^{1}$ and Aleksan Shanoyan ${ }^{2}$ \\ ${ }^{1}$ Department of Agricultural and Applied Economics, University of Wyoming, Laramie, WY 82071, USA and ${ }^{2}$ Department of \\ Agricultural Economics, Kansas State University, Manhattan, KS 66506, USA \\ *Corresponding author. Email: vhovhann@uwyo.edu
}

\begin{abstract}
We investigate food preference changes in Russia that may have resulted from political, economic, and other changes. Our empirical framework utilizes advances in consumer theory and exploits provincial-level panel data on food consumption and supply shifters to identify price and income effects. Our findings indicate that consumers underwent a structural preference change that began in 2007 and continued into 2014. To illustrate the magnitude of this change, we contrast economic effects for select food commodities across regions. The new insights will be useful in designing timely and effective food and trade policies, as well as informing strategy decisions of agribusiness industry players.
\end{abstract}

Keywords: Food demand in Russia; pre-committed demand; structural food preference change

JEL Classifications: D11; D12

\section{Introduction}

Following the collapse of the Soviet Union and a decade-long economic transition, the Russian Federation (Russia) has emerged as a major player in regional and global trade. By 2008, Russian exports reached $\$ 472$ billion ( $2.9 \%$ of world exports) as a result of the steady increase at an average annual rate of $21 \%$ during $2000-2008$, while imports totaled an estimated $\$ 292$ billion (1.8\% of world imports) following an average growth rate of $26 \%$ per year over the same period (World Trade Organization, 2009). Consequently, Russia became one of the top 20 trading countries in the world. Despite the fact that the economic recession brought by global financial crisis and plummeting oil prices at the end of 2008 interrupted the impressive economic growth, the trade bounced back in subsequent decade toward pre-crisis levels with exports reaching upwards of $\$ 450$ billion and imports exceeding $\$ 237$ billion in 2018 (Cooper, 2009; ITC, 2019). The economic transition accompanied by trade liberalization and inflows of foreign direct investments have altered the structure of domestic food markets and their level of integration with global agrifood systems. For example, the "western-style mass grocery retail" model with global procurement networks has gained popularity among Russian consumers with the combined share thereof reaching $68 \%$ of the total number of grocery stores in 2017 (WorldFood Moscow, 2018a).

Evidence suggests that these political and economic changes in the country have gone hand-inhand with observable dietary shifts. Initial years of price liberalization and the subsequent decline in real incomes reduced demand for meat and dairy products considerably, but meat consumption

(C) The Author(s) 2020. This is an Open Access article, distributed under the terms of the Creative Commons Attribution-NonCommercialShareAlike licence (http://creativecommons.org/licenses/by-nc-sa/4.0/), which permits non-commercial re-use, distribution, and reproduction in any medium, provided the same Creative Commons licence is included and the original work is properly cited. The written permission of Cambridge University Press must be obtained for commercial re-use. 
regained its pre-change levels shortly afterwards (Liefert, Lohmar, and Serova, 2003; Vorotnikov, 2017). More recent evidence indicates growing popularity of fresh produce, and notable compositional shifts in meat, bread, and cereal consumption due in part to health-related reasons (Harvard Medical School, 2015; ITEFood\&Drink, 2017; Ratushnaya and Savenkov, 2019; Vorotnikov, 2018, WorldFood Moscow, 2018b). With a continued rise in incomes, the overall trend seems to be a growing affinity for food quality rather than quantity (Manig and Moneta, 2014). Finally, the series of recent economic sanctions imposed by Russia on a range of agricultural products imported from a number of western nations (e.g., the EU, USA, Canada, Australia, etc.) have likely resulted in new shifts in food consumption patterns. The extent to which these shifts are prompted by underlying structural changes in consumer food preferences rather than being reflective of sheer consumer response to economic drivers under stable preferences remains largely unknown.

Despite the growing importance of Russia's role in the global agrifood trade, however, there is still a paucity of empirical research examining the food demand structure in Russia and possible consumer preference changes. With a broader aim to contribute to filling this gap in the literature, the objective of this study is to quantify consumer demand for a number of widely consumed food commodities and to conduct a formal analysis of structural food preference change. In the spirit of Dong and Fuller (2010) and Hovhannisyan and Gould (2014), structural preference change is defined as a change in structural demand parameters, which indicates a change in the underlying consumer behavior, and may well be induced by urbanization, policies, health concerns, new information regarding health benefits of food, shifts in consumer tastes, etc. ${ }^{1}$ The insights generated by this study should offer relevant information to national and supranational policy makers and global agrifood industry stakeholders. For example, it may improve the decision-making process underlying the domestic food and health policies that strive to divert unhealthy dietary shifts toward more desirable health outcomes through a variety of tools such as subsidies/taxes, grading standards, food labels, and dietary information campaigns (Haddad, 2003). Similarly, a finding that indicates a shift in consumer diets toward reduced reliance on wheat and other cereals may help the farmers in the USA and other major wheat producing countries anticipate a further boost in Russian wheat exports (currently, Russia is the largest wheat exporter with a $20.5 \%$ share of global wheat exports) and more intense competition in the world wheat markets, thus prompting them to develop strategies to cope with such potential challenge.

This study extends the body of literature in three distinct ways. First, our analytical framework exploits the recent advances in consumer demand literature by utilizing the Generalized Exact Affine Stone Index (GEASI) system, a demand model that extends the EASI demand specification of Lewbel and Pendakur (2009) to include potential pre-committed demand (Hovhannisyan and Shanoyan, 2019). ${ }^{2}$ Specifically, we modify the GEASI model by incorporating a time transition function in the spirit of Ohtani and Katayama (1986) to examine potential structural preference shifts. While retaining all of the desirable properties of the previous workhorse demand models such as the Almost Ideal Demand System (AIDS) (Deaton and Muellbauer, 1980; Hovhannisyan and Khachatryan, 2017), the GEASI system offers a number of unique advantages due to its ability

\footnotetext{
${ }^{1}$ According to this approach, a structural preference change is tantamount to a change in indifference curves. Intuitively, one would be able to detect this change, if, for example, consumer food choices change following a proportionate increase in all prices and income that leaves the budget constraint intact. In reality, however, economic variables hardly follow identical patterns; thus, there is a need for a formal analysis that controls for changes in economic variables and allows quantifying shifts in structural demand parameters. These parameters underlie utility functions and determine the shapes of indifference curves, with the parameter shifts indicating structural changes in preferences.

${ }^{2}$ Pre-committed demand is a demand component that is insensitive to price and income changes (Tonsor and Marsh, 2007). Over the pre-committed portion of demand, prices play little role in affecting consumer behavior. Ignoring precommitments, when they exist, results in their effects being wrongly attributed to other demand determinants included in the model, which can generate inconsistent demand parameter estimates and erroneous policy implications (Rowland, Mjelde, and Dharmasena, 2017).
} 
to: (i) account for unobserved consumer heterogeneity, (ii) allow for unrestricted Engel curves whose structure is determined by data rather than being imposed a priori (Pendakur, 2009; Samuelson, 1948; Stone, 1954), (iii) account for potential pre-commitment bias in empirical settings, where pre-committed quantities constitute an integral part of consumer demand (Hovhannisyan and Shanoyan, 2019; Rowland, Mjelde, and S. Dharmasena, 2017), and (iv) assure invariance of elasticity estimates to the data measurement units (Alston, Chalfant, and Piggott, 2001).

Second, our empirical framework accounts for price endogeneity resulting from the omission of the supply side of price determination process by constructing a system of reduced-form price equations that relate food prices to exogenous agricultural commodity supply shifters (Dhar, Chavas and Gould, 2003). Ignoring the simultaneity bias can distort the estimates of consumer demand structure and can lead to erroneous policy recommendations (e.g., Hovhannisyan and Bozic, 2017).

Third, given our use of the most current and longest provincial-level panel data available, which cover a period of 11 years, we are able to account for the effects of unobserved provincial heterogeneity (e.g., deeply rooted regional food customs, cultures, and traditions) on food consumption patterns. Thus, our empirical framework has the potential of generating more accurate estimates of consumer demand structure, which may be useful in designing timely and effective food and trade policies, as well as informing strategy decisions of agribusiness industry players.

Our major findings indicate that consumers in Russia underwent structural food preference changes that began in 2007 and continued into 2014. For example, vegetables have gained popularity as is evidenced by the rising magnitude of the respective income elasticities of demand, while consumer preferences for sugar, cereal, and meat products have declined in the majority of the regions in our sample, suggesting perhaps consumer saturation in these commodities. To highlight the importance of modeling potential preference change, we further conduct a series of experiments examining consumer welfare effects of both actual and hypothetical food price changes.

The rest of the paper is organized as follows: Section 2 presents the background for this study. Section 3 describes the methodology for examining structural food preference change, as well as discusses price endogeneity and the empirical technique to address it. Section 4 offers a brief description of the data and the main variables analyzed. Section 5 presents the empirical results. Finally, Section 6 summarizes the major findings of this study and the implications for Russia and its trading partners.

\section{Background and literature review}

Major changes in food consumption patterns and shifts in composition of consumer diets have been a noteworthy phenomenon observed in many parts of the world in recent decades (Hovhannisyan and Devadoss, 2020; Hovhannisyan and Gould, 2011; Regmi, 2001; Sharma, Nguyen, and Grote, 2018). Some of the most important changes have been the increased consumer demand for organic, local, environmentally friendly, sustainable, and functional foods that offer benefits beyond basic nutrition (e.g., Kearney, 2010). Despite these commonalities in food consumption trends, transition in dietary patterns has been found to vary by country due mainly to economic, socio-demographic and cultural differences, as well as urbanization and trade liberalization policies (Kearney, 2010; Popkin, Adair, and Ng, 2012).

Similar to the rest of the world, Russia has not been immune to nutrition transition. However, several special drivers set the country apart from many other consumer markets, an important one of which is the transition from a centrally planned to a market economy. Prior to this transition, the bulk of the nation's food supply was provided by large state collective farms that were guided by 5 -year long centralized economic plans. These plans were determined by state planning commissions that followed a top-down approach to policy decisions, oftentimes with little regard for consumer tastes, preferences, and desires (Sachs and Woo, 1994). Given the lack of foreign-supplied alternatives, consumer food choices were heavily influenced by planners' preferences, which sought to expand the production of high-value livestock and dairy products 
(Liefert, Lohmar, and Serova, 2003). Consequently, the initial years of post-transformation went hand-in-hand with increasing consumer sovereignty and saw a considerable decline in per capita consumption of meat and dairy products. Meanwhile, consumption of bread, potatoes, and other food staples remained relatively stable (Liefert and Swinnen, 2002). ${ }^{3}$

Trade liberalization that was carried out as an integral part of the economic transition is widely thought to have further contributed to changing consumer diets (Liefert, Lohmar, and Serova, 2003). Specifically, free trade with the rest of the world revealed Russia's competitive disadvantage in the production of a number of agricultural products, including livestock and related products. As a result, the share of foreign-supplied agricultural products in domestic consumption increased, and as imports continued to grow and Russian consumers became increasingly reliant on imported food products, the drop in the consumption of livestock and similar products were somewhat mitigated (Liefert, 2002). Finally, price liberalization brought by the economic transition led to prices outstripping consumer incomes, which consequently reduced real income. This further reinforced the changes in livestock and dairy consumption, given the relatively higher income elasticities of demand for these food products (Liefert, Lohmar, and Serova, 2003).

Evidence suggests that consumer food tastes and preferences have continued to evolve during the early 2000s and through modern-day Russia. For example, meat consumption bounced back after years of decline and eventually exceeded the Soviet-era levels when per capita meat consumption reached $75 \mathrm{~kg}$ in 2017 (Vorotnikov, 2017). An even more important change may have been a compositional shift in meat consumption with poultry and pork having gained popularity in recent years, while beef consumption remained relatively stable (FAS/USDA, 2015). Recent years have also seen a considerable increase in fresh fruit and vegetable consumption, which has been occurring at an average annual rate of $4 \%$ (WorldFood Moscow, 2018a). As a result, per capita vegetable consumption reached $112 \mathrm{~kg}$ in 2016, with potato, the "almighty Russian crop" continuing to be the most widely consumed vegetable (Fresh Plaza, 2017). With a steady rise in disposable income, however, potatoes are expected to be slowly replaced by other food products that are perceived as normal goods by Russian consumers.

In contrast, per capita consumption of dairy products stagnated and eventually declined to $233.4 \mathrm{~kg}$ in 2016, with the decline amounting to $9 \mathrm{~kg}$ over 2013-2015 alone (Meatinfo, 2020). This change in dairy consumption may be partially due to various milk adulteration practices such as substituting palm oil for milk, which, according to some expert estimates, have been affecting a quarter of dairy production in Russia (Barsukova, 2016). This creates important opportunities for Russia's trade partners, given the sizable gap between the actual and recommended dairy consumption (i.e., $325 \mathrm{~kg}$ annually) and the fact that Russian consumers expressed willingness to increase their dairy consumption, provided that product quality improves (Dairy Global, 2019).

A final important group of food categories deserving scrutiny comprises bread, pastry, other bakery goods, and cereals. Despite their historical significance from the perspective of dietary composition, consumption of many of these products has been on a decline due in part to high caloric intake and resultant health issues (Harvard Medical School, 2015). Evidence also suggests that artisan and whole grain breads have become increasingly popular with younger consumers, who highly value food freshness and quality. As a result, artisan bread became a market leader in 2016 with a 32\% market share (ITEFood\&Drink, 2017). In addition to quality features, consumers have also shown growing interest in cereal products that are convenient to store and offer longer-shelf-life. This led to an 11\% increase in demand for these products in 2014 alone (ITEFood\&Drink, 2017).

Consumption changes immediately following the break-up of the command economy were clearly a result of consumer preferences taking precedence over planners' preferences. Later changes, however, were in all likelihood driven by a combination of factors such as the economic growth in the mid-2000s, improved food accessibility and availability, and more recent food safety

\footnotetext{
${ }^{3}$ Liefert, Lohmar, and Serova (2003) offer a detailed description of the interplay between the planner and consumer preferences that also take into account the production-possibility frontier of the economy in question.
} 
issues that altered consumer incomes, food prices, and tastes and preferences. ${ }^{4}$ The series of recent economic sanctions imposed by Russia on a range of imported agricultural products from a number of western nations may have further contributed to changes in food consumption patterns through their effects on the availability, variety, and accessibility of food products in the country's domestic markets (Liefert and Liefert, 2015). Nevertheless, the extent to which these recent consumption changes are tied to shifting consumer tastes and preferences rather than being reflective of sheer consumer response to changing economic circumstances under stable preferences has not received adequate research interest. Previous studies have almost exclusively focused on estimating the structure of demand for various food products based on an implicit assumption of fixed and exogenously given consumer preferences, where consumption changes are fully attributed to consumer response to changing opportunity set (e.g., Burggraf et al., 2015; Elsner, 1999; Hovhannisyan and Shanoyan, 2019; and Staudigel and Schröck, 2015). However, structural changes can have significant effects on food preferences, the omission of which can result in inaccurate price and income effects, ultimately leading to erroneous policy implications.

We fill this gap by conducting a formal analysis of structural food preference change in Russia by adopting an advanced demand model and by utilizing the best time series of provincial-level panel data available. More specifically, we follow a large strand of literature by adopting a parametric approach to the analysis of consumer tastes and preferences (Okrent and Alston, 2011). Earlier studies in this line of literature evaluated structural change in terms of the inconsistency of model parameters with restrictions stemming from consumer theory (e.g., Blanciforti, Green, and King, 1986) or relied on a Chow-type test for assessing the stability of behavioral parameters (e.g., Chavas, 1983; Goodwin, 1989; Menkhaus, Clair and Hallingbye, 1985).

We follow the most recent studies that adopt a more direct approach, whereby the structural parameters underlying consumer preferences are allowed to vary according to a variety of time transition functions, tested for stability, with a finding of instability interpreted as evidence of preference change (e.g., Dong and Fuller, 2010; Hovhannisyan and Gould, 2014; Moschini, Moro, and Green, 1994). In an empirical application of this framework to the analysis of food demand in China, for example, Hovhannisyan and Gould (2014) found that consumers had undergone considerable preference changes in the recent years with meats and fruits replacing roots and tubers in the traditional Chinese food diet, while relatively older consumers with lower levels of educational attainment were found to be immune to these dietary transitions. However, these results need to be interpreted with caution as econometric issues such as price endogeneity were not addressed in the previous analyses. Our study, on the other hand, provides the first attempt at addressing food price endogeneity in a structural preference change context.

A nonparametric method represents an alternative way of analyzing consumer preference change that has been used extensively in the past literature. The essence of this approach consists in assessing the consistency of food consumption data in hand with the generalized (GARP), strong (SARP), and weak axioms of revealed preferences (WARP), with a finding of consistency interpreted as a lack of preference change (e.g., Bergtold, Akobundu, and Peterson, 2004; Brester and Schroeder, 1995; Chalfant and Alston, 1988). However, a major downside of this test has been found to be the lack of power in detecting preference change when aggregate data are utilized in the analyses, which may paradoxically lead to a conclusion of stable consumer preferences even when the actual reality is different (Okrent and Alston, 2011). Therefore, we confine our attention to the parametric methods that utilize a switching regression framework developed by Ohtani and Katayama (1986) and popularized by a number of studies such as Moschini and Meilke (1989) and Dong and Fuller (2010). This analytical framework allows for estimating potential change in

\footnotetext{
${ }^{4}$ Achieving complete self-sufficiency in pork and poultry products and its effects on food consumption offers a case in point. This has been an important political goal long pursued by the Russian government, after the fulfillment of which the country will strive for self-sufficiency in beef. For example, the government has waived the VAT at every stage of beef production until 2021 (Vorotnikov, 2016).
} 
structural parameters of the model by specifying all the possible permutations of starting and ending points of the change, thus allowing for the possibility of both abrupt and gradual change.

\section{Methodology}

In this section, we provide a brief discussion of the GEASI demand system underlying our empirical analysis. Next, we extend the GEASI via the incorporation of a time transition function that allows for evaluating structural food preference changes. Finally, we discuss price endogeneity and the resulting effects brought by the constant shifts of supply and demand curves, as well as present an identification strategy to address this econometric issue.

\subsection{A Generalized Exact Affine Stone Index demand specification}

Let $w_{i}, p_{i}$, and $c_{i}$ denote the budget share, price, and pre-committed demand (i.e., invariant to income and price changes) for product $i$, respectively, $X$ denote household total food and non-food expenditures, $\varepsilon_{i}$ reflect unobserved preference heterogeneity, and $\alpha_{i k}$, $\beta_{i r}$ be parameters representing the price and income effects on demand. The GEASI demand model can then be represented by the following system of equations (Hovhannisyan and Shanoyan, 2019):

$$
w_{i}=\frac{c_{i} p_{i}}{X}+\left(1-\frac{c^{\prime} p}{X}\right)\left(\sum_{l=0}^{L} \beta_{i l}\left(\ln \left(X-c^{\prime} p\right)-w^{\prime} \ln p\right)^{l}+\sum_{k=1}^{N} \alpha_{i k} \ln p_{k}\right)+\varepsilon_{i}, \quad \forall i=1, \ldots, N,
$$

where $\left(\ln \left(X-c^{\prime} p\right)-w^{\prime} \ln p\right)$ is price and pre-commitment $(c)$-adjusted total expenditure that captures the effects of real income; $r$ denotes the order of the polynomial function of real income; $c^{\prime} p$ represents pre-committed expenditures; and $\left(X-c^{\prime} p\right)$ reflects supernumerary expenditures ${ }^{5}$ that are driven by economic variables. The demand system in (1) is subject to the theoretical restrictions of adding-up $\sum_{i=1}^{N} \beta_{i 0}=1 ; \sum_{i=1}^{N} \beta_{i l}=0, \forall l=1, \ldots, L ; \sum_{i=1}^{N} \alpha_{i k}=0(\forall k=1, \ldots, N)$, and symmetry $\alpha_{i k}=\alpha_{k i}(\forall i, k=1, \ldots, N)$.

An important advantage of modeling pre-committed consumption that the GEASI provides is the more accurate estimation of price and income elasticities of demand. Specifically, elasticities measured in a given empirical setting reflect a summary estimate of consumer income and price responsiveness over both pre-committed and discretionary portions of a demand curve; thus, overlooking pre-committed quantities wrongly attributes consumer insensitivity to all consumption and results in less elastic estimates of economic effects (Rowland et al., 2017).

\subsection{A Generalized Exact Affine Stone Index-based analytical framework for structural preference change}

We modify the GEASI model by introducing a time transition function that resembles a gradual switching regression and is adopted from Ohtani and Katayama (1986):

$$
\begin{gathered}
h_{t}=0, \text { for } t=1, \ldots, \tau_{1} \\
h_{t}=\frac{\left(t-\tau_{1}\right)}{\left(t-\tau_{2}\right)}, \text { for } t=\tau_{1}+1, \ldots, \tau_{2}-1 \\
h_{t}=1, \text { for } t=\tau_{2}, \ldots, T,
\end{gathered}
$$

\footnotetext{
${ }^{5}$ Unlike pre-committed demand, supernumerary consumption is solely determined by prices and consumer income, and once pre-commitments are satisfied, consumers become highly sensitive to changes in economic variables.
} 
where $\tau_{1}$ denotes the end of the first regime, and $\tau_{2}$ indicates the beginning of the second regime (i.e., $\tau_{1}<\tau_{2}$ ), and the period between $\tau_{1}$ and $\tau_{2}$ captures the transition path (i.e., $\tau_{1}+1=\tau_{2}$ is indicative of an abrupt change, whereas $\tau_{1}+1<\tau_{2}$ is interpreted as gradual transition).

Incorporation of the time transition function in equation (2) into the GEASI system in equation (1) generates the following model that allows for the evaluation of preference change: ${ }^{6}$

$$
w_{i r t}=\frac{c_{i}^{h} p_{i r t}}{X_{r t}}+\left(1-\frac{c^{h \prime} p}{X_{r t}}\right)\left(\sum_{l=0}^{L} \beta_{i l}^{h}\left(\ln \left(X_{r t}-c^{h \prime} p\right)-w^{\prime} \ln p\right)^{l}+\sum_{k=1}^{N} \alpha_{i k}^{h} \ln p_{k r t}\right)+\xi_{i r t},
$$

where $c_{i}^{h}=c_{i 0}+c_{i 1}^{h} h_{t}, \quad \beta_{i l}^{h}=\beta_{i l 0}+\beta_{i l 1}^{h} h_{t}, \alpha_{i k}^{h}=\alpha_{i k 0}+\alpha_{i k 1}^{h} h_{t} ;$ and $\sum_{i=1}^{N} \beta_{i l 1}^{h}=0 ; \forall l=1, \ldots, L$, $\sum_{i=1}^{N} \alpha_{i k 1}^{h}=0, \forall k=1, \ldots, N$ present an additional set of restrictions to be imposed on the system.

Finally, we adjust the elasticity formulas derived by Hovhannisyan and Shanoyan (2019) to reflect the underlying demand specification in equation (3) and to allow for the assessment of potential structural parameter change.

\subsection{Price endogeneity and the identification strategy}

An important distinguishing characteristic of agricultural production is its exposure to disease, weather, climate, and natural calamities, which usually generate large swings in the supply of food commodities. When combined with the inelastic food demand, supply instability can generate considerable price variability in agriculture. Evidence suggests that these unpredictable supply forces are indeed some of the most important drivers behind agricultural price volatility (Gilbert, 2010). Despite this reality, literature on food demand in Russia has overlooked this particular source of price variation because of limited data, thus relying only on demand factors for the identification of structural demand parameters (Shiptsova, Goodwin, and Holcomb, 2004; Staudigel, and Schröck, 2015). This creates an endogeneity bias given that the error terms in the commodity demand equations reflect both unobserved demand and supply effects and can generate inconsistent parameter estimates and economic effects, ultimately leading to erroneous policy recommendations (Hovhannisyan and Bozic, 2017). For example, the recent expansion in the Russian grain, pork, and poultry production driven by the country's desire for self-sufficiency in light of the recent developments in the global trade protectionism may be wrongly attributed to growing demand for these products and not the push from the government to expand these industries. Similarly, drought-induced feed price spikes and resulting beef cow herd liquidation may create an impression of structural changes in consumer tastes and preferences, when no such changes are present.

To address price endogeneity, we follow Dhar, Chavas, and Gould (2003) to supplement our demand system by reduced-form supply equations. These equations express food commodity prices in terms of exogenous supply determinants such as temperature, rainfall, and pollution, ${ }^{7}$ thus making it possible to disentangle the simultaneous effects of demand and supply forces on agricultural prices and quantities, as presented below: ${ }^{8}$

\footnotetext{
${ }^{6} \mathrm{We}$ acknowledge that the assumption that all parameters follow the same transition pattern may be restrictive.

${ }^{7}$ Price instruments that satisfy both the relevance and exogeneity requirements and are measured at a regional level can be difficult, if not impossible to come by in practice.

${ }^{8} \mathrm{We}$ acknowledge the possibility of lagged effects of supply shocks for storable commodities. However, for the sake of simplifying analyses already complicated by the inclusion of regional fixed-effects and time transition function, and to ensure our model converges, we do not account for these potential dynamic effects in this application.
} 


$$
\begin{aligned}
\ln \left(p_{i r t}\right)= & \mu_{i 0}+\mu_{i 1} \mathrm{RF}_{-} 1_{r t}+\mu_{i 2} \mathrm{RF}_{-} 2_{r t}+\mu_{i 3} \mathrm{TP}_{-} 1_{r t}+\mu_{i 4} \mathrm{TP} \_2_{r t}+\mu_{i 5} \mathrm{GSE}_{r t}+\mu_{i 6} \mathrm{PW}_{r t} \\
& +\mu_{i 7} \mathrm{ALPC}_{r t}+\mu_{i 8} \mathrm{FW}_{r t}+\varsigma_{i r t}, \forall i=1, \ldots, N ; r=1, \ldots, R ; t=1, \ldots, T .
\end{aligned}
$$

where RF_ $1_{r t}$ and RF_2 ${ }_{r t}$ measure January and July rainfall in region $r$ in year $t(\mathrm{~mm}), \mathrm{TP}_{-} 1_{r t}$ and $\mathrm{TP} \_2_{r t}$ denote January and July temperatures in region $r$ in year $t\left({ }^{\circ} \mathrm{C}\right)$, respectively, GSE $\mathrm{G}_{r t}$ denotes the amount of gas emitted (1,000 metric tons), $\mathrm{PW}_{r t}$ represents the amount of polluted water used in region $r$ in year $t$ (million $\left.\mathrm{m}^{3}\right), \mathrm{ALPC}_{r t}$ reflects agricultural land per rural resident $(1,000 \mathrm{ha})$, $\mathrm{FW}_{r t}$ measures the amount of freshwater used in agricultural production (million $\mathrm{m}^{3}$ ), $\varsigma_{\text {irt }}$ is the residual of the $i^{\text {th }}$ reduced-form supply equation, and $\mu_{i 0}-\mu_{i 8}$ are parameters.

The agricultural commodity supply determinants utilized in this study are expected to affect prices through their influence on commodity stocks (Headey and Fan, 2008). For example, extremely high temperatures and lack of rainfall can lead to an unfavorable impact on crop yields and food supply, thus generating upward pressure on prices, ceteris paribus. Similarly, expanding agricultural land base can lead to crop production growth and subsequent downward pressure on agricultural prices. Therefore, we anticipate that our supply shifters satisfy the instrument relevance condition. Additionally, our supply factors, especially the ones related to weather, climate, and pollution, reflect unforeseeable supply shocks that are properly excluded from commodity demand equations and are distinct from unobserved demand determinants, thus satisfying the instrument exogeneity requirement.

\section{Provincial-level food consumption data}

Our empirical application is based on provincial-level food consumption data obtained from the Federal State Statistics Service (FSSS) of Russia. The FSSS compiles information regarding household income, food consumption, expenditures, consumer socio-economic and demographic characteristics, as well as agricultural production and other related aspects of Russian households using a representative sample of consumers from more than 70 administrative divisions (e.g., oblasts and autonomous republics). Quarterly surveys are conducted within the framework of the Household Income and Food Expenditure Survey based on a two-stage stratified systematic random sampling method. Specifically, a third of the households sampled are dropped each period and replaced with a new sample of the same size using a rotating-sample design. The householdlevel data are subsequently aggregated by the FSSS to the administrative division level, and from quarterly to annual level before the data are made publicly available (Hovhannisyan and Shanoyan, 2019).

In the current study, we confine our analysis to the consumer demand structure for seven food commodity aggregates, namely meats, vegetables, cereals, eggs, vegetable oils, sugar, and dairy, which we supplement by a composite numéraire good to account for the consumption of other food and non-food goods (denoted by "other"). Our choice of this approach reflects its advantage in sidestepping potential undesirable consequences of two-stage budgeting or separability assumptions that have been used widely in previous literature (e.g., Moschini, Moro, and Green, 1994; Zhen et al., 2013). Categorizing the seven commodity groups and numéraire good generates 5,896 total observations over 11 years (i.e., 2006-2016) and across 67 regions. We limit our empirical analysis to 67 regions/administrative units (mainly called oblasts) due to limited data on price instruments from the remaining regions. Online supplementary appendix presents all the regions comprising Russia, meanwhile highlighting the ones underlying the current study.

As can be seen from the descriptive statistics presented in Table 1, food expenditures continue to make up an important share of consumer income in Russia. Specifically, meats, cereals, dairy, vegetables, sugar, eggs, and vegetable oils collectively account for $47.8 \%$ of income, while the remaining $52.1 \%$ is allocated to other food and non-food items purchased by a typical Russian 
Table 1. Descriptive statistics

\begin{tabular}{|c|c|c|c|c|}
\hline Variable & Mean & STD & Min & Max \\
\hline \multicolumn{5}{|l|}{ Per capita annual expenditures (1,000 Rubles) } \\
\hline Meats & 12.83 & 5.21 & 3.95 & 37.59 \\
\hline Vegetables & 4.62 & 2.00 & 1.18 & 16.51 \\
\hline Cereals & 6.40 & 2.35 & 2.03 & 16.78 \\
\hline Eggs & 0.84 & 0.32 & 0.28 & 2.36 \\
\hline Fats/oils & 0.73 & 0.23 & 0.25 & 2.00 \\
\hline Sugar & 2.93 & 1.23 & 0.87 & 9.00 \\
\hline Dairy & 6.38 & 2.82 & 1.75 & 22.22 \\
\hline Other & 113.92 & 57.24 & 12.22 & 336.53 \\
\hline \multicolumn{5}{|l|}{ Agricultural commodity price (Rubles/kg) } \\
\hline Meats & 190.28 & 70.71 & 57.97 & 512.82 \\
\hline Vegetables & 45.36 & 21.23 & 7.50 & 192.01 \\
\hline Cereals & 54.76 & 22.54 & 15.80 & 162.20 \\
\hline Eggs & 3.47 & 1.57 & 1.21 & 12.06 \\
\hline Fats/oils & 59.71 & 19.43 & 12.52 & 157.32 \\
\hline Sugar & 78.69 & 36.14 & 17.42 & 248.76 \\
\hline Dairy & 28.21 & 15.53 & 6.17 & 143.89 \\
\hline Other (CPI for consumer goods) & 109.31 & 3.11 & 103.50 & 119.30 \\
\hline \multicolumn{5}{|l|}{ Price instruments } \\
\hline Gas emissions ( 1,000 tons) & 243.94 & 516.47 & 2.00 & $4,086.00$ \\
\hline Polluted eater (million $\mathrm{m}^{3}$ ) & 163.26 & 219.65 & 0.20 & $3,578.00$ \\
\hline January temperature $\left({ }^{\circ} \mathrm{C}\right)$ & -12.16 & 7.98 & -39.40 & 4.90 \\
\hline July temperature $\left({ }^{\circ} \mathrm{C}\right)$ & 19.47 & 3.40 & 10.00 & 29.60 \\
\hline January rainfall $(\mathrm{mm})$ & 35.86 & 22.51 & 1.00 & 168.00 \\
\hline July rainfall (mm) & 67.47 & 36.95 & 3.00 & 319.00 \\
\hline Freshwater (million $\mathrm{m}^{3}$ ) & 651.40 & 820.64 & 7.00 & $4,061.00$ \\
\hline Per capita ag. land (1,000 ha) & 65.91 & 66.40 & 1.71 & 309.42 \\
\hline \multicolumn{5}{|l|}{ Budget share $(\%)$} \\
\hline Meats & 6.26 & 1.34 & 3.32 & 12.55 \\
\hline Vegetables & 2.24 & 0.47 & 1.11 & 3.73 \\
\hline Cereals & 3.17 & 0.71 & 1.58 & 6.02 \\
\hline Eggs & 0.42 & 0.11 & 0.18 & 0.93 \\
\hline Fats/oils & 0.38 & 0.12 & 0.16 & 1.07 \\
\hline Sugar & 1.43 & 0.6 & 0.63 & 3.18 \\
\hline Dairy & 3.07 & 0.61 & 1.44 & 5.42 \\
\hline Other & 52.13 & 8.96 & 19.04 & 75.84 \\
\hline Per capita annual income (1,000 Rubles) & 214.40 & 97.03 & 41.48 & 613.49 \\
\hline
\end{tabular}

Source: Federal State Statistics Service of Russian Federation, 2006-2016. 
consumer. Using commodity expenditures and the respective consumption amounts, we further compute commodity unit values as proxies for food category prices.

Table 1 also provides descriptive statistics for a variety of weather-related variables and those reflecting agricultural production capacity that have been utilized in the demand system estimation to address food price endogeneity resulting from the simultaneous determination of supply and demand. These instruments manifest considerable spatial variation across the Russian regions, which is essential from the identification perspective. For example, agricultural land availability ranges from as low as 1.7 ha per rural resident in Murmansk to as high as 309.4 ha in Saratov. Similarly, greenhouse gas emissions extend from two thousand tons in KabardinoBalkaria to 4,086 thousand tons in Tyumen, where the majority of oil and gas reserves and processing industries are concentrated. Due in part to this reason, Tyumen is also responsible for the highest amount $\left(4,061\right.$ million $\left.\mathrm{m}^{3}\right)$ of freshwater use, while annual average freshwater consumption in Altai barely reached seven million $\mathrm{m}^{3}$. Additionally, we utilize data on polluted water in an attempt to account for the potential adverse effects of deteriorating water quality on agricultural production and commodity prices. Similar to other price instruments, water pollution appears to vary appreciably from 0.2 million $\mathrm{m}^{3}$ in the Altai Republic to 3,578 million $\mathrm{m}^{3}$ in Perm. Finally, Russian climate is continental and characterized by dry warm/hot summers (June temperature is $29.6^{\circ} \mathrm{C}$ in Samara) to cold winters (January temperature is $-39.4^{\circ} \mathrm{C}$ in Yakutia), given the high latitude of the country (i.e., $40-75^{\circ} \mathrm{N}$ ), with considerable provincial heterogeneity in terms of precipitation (e.g., 1-168 mm in January for Primorsk and Kaliningrad, respectively, and 3-319 mm in June for Astrakhan and Primorsk, respectively).

To explore the possibility of food preference change in Russia, as well as to shed light on the directions of potential dietary transition, we utilize spatial and temporal analyses of food consumption and income. As a first step, we perform a simple comparison of consumption of select food commodities (i.e., dairy, meat, and vegetables) in years 2006 and 2016. Specifically, vegetable consumption has undergone the most impressive change in this 11-year span, with almost all the provinces considered experiencing a sizable rise in the consumption of this food category. In contrast, dairy consumption has been on a decline in the majority of provinces under scrutiny, while increasing in a relatively small number of regions. Some of these changes may be driven by the food safety concerns triggered by a series of fraudulent activities in the country's dairy industry. Finally, meat consumption seems to have increased across the most provinces, although at a lower rate vis-à-vis vegetable consumption, which may be reflective of the increased government role in promoting the domestic consumption of meats.

Next, we juxtapose dynamics in meat consumption and income distributions over the sample period. As can be observed from online supplementary appendix, both meat consumption and income have undergone notable changes during this period, with both distributions shifting rightward, in the meantime becoming more dispersed. However, the rate of increase in income appears to have outstripped that in meat consumption, which may be reflective of Engel's law. Alternatively, this finding may be indicative of changes in consumer preferences for meat products. Finally, we recognize the possibility of a host of other important factors affecting food consumption, which cannot be fully accounted for in our graphical analysis. Therefore, next we turn to a formal econometric analysis of possible food preference change in Russia.

We acknowledge that our use of the household food expenditure data aggregated to oblast level may present some challenges that are not straightforward to address, the most important of which is, perhaps, the accurate representation of unobserved consumer heterogeneity. More specifically, location-based aggregation of individual consumers may mask the true effects of unobserved consumer characteristics on consumption-related decisions, ultimately affecting multilevel inferences on consumer behavior (Clark and Avery, 1976). As a side note, however, the effects of data aggregation remain an empirical issue that may vary by the empirical setting considered (Cramer, 1964). Further, we recognize that limited data restrict our ability to investigate consumer behavior in the early years of the economic transition, which would most likely uncover even more 
impressive shifts in consumer preferences, when the latter took precedence over planners' preferences. Therefore, future studies should take advantage of more disaggregate data.

\section{Empirical strategy and results}

We estimate the following simultaneous system of demand and reduced-form price equations via the full information maximum likelihood (FIML) estimation procedure: ${ }^{9}$

$$
\begin{gathered}
w_{i r t}=\frac{\tilde{c}_{i}^{h} p_{i r t}}{X_{r t}}+\left(1-\tilde{c}^{h \prime} p X_{r t}\right)\left(\sum_{l=0}^{L} \beta_{i l}^{h}\left(\ln \left(X_{r t}-\tilde{c}^{h \prime} p\right)-w^{\prime} \ln p\right)^{l}+\sum_{k=1}^{N} \alpha_{i k}^{h} \ln p_{k r t}\right)+\xi_{i r t}, \\
\ln \left(p_{i r t}\right)=\mu_{i 0}+\mu_{i 1} \mathrm{RF}_{-} 1_{r t}+\mu_{i 2} \mathrm{RF}_{-} 2_{r t}+\mu_{i 3} \mathrm{TP}_{-} 1_{r t}+\mu_{i 4} \mathrm{TP} 2_{r t}+\mu_{i 5} \mathrm{GSE}_{r t}+\mu_{i 6} \mathrm{PW}_{r t} \\
\quad+\mu_{i 7} \mathrm{ALPC}_{r t}+\mu_{i 8} \mathrm{FW}_{r t}+\varsigma_{i r t}, \\
\forall i=1, \ldots, 8 ; r=1, \ldots, 68 ; t=1, \ldots, 11,
\end{gathered}
$$

where province fixed-effects are incorporated into the commodity demand functions through a demographic translation of pre-committed demand $\tilde{c}_{i}^{h}=c_{i 0}+\sum_{r=1}^{11} c_{i r} f_{i r}+\left(c_{i 0}^{h}+\sum_{r=1}^{11} c_{i r}^{h} f_{i r}+\right) h$ (Pollak and Wales, 1981). When applied to the GEASI model, demographic translation assures invariance of elasticity estimates to the data measurement units, an important feature the EASI model lacks (Alston, Chalfant, and Piggott, 2001).

Table 2 presents the results from a series of econometric tests. First, we determine the proper Engel curve structure by fitting polynomials of different orders that vary from a first to a seventh degree. Based on a likelihood ratio test outcome, we find that the quartic Engel curve provides the best fit of the data, and thus adding higher degrees of curvilinearity does not significantly enhance the explanatory power of the model. ${ }^{10}$ Second, we find strong empirical evidence for precommitted demand, which indicates that the GEASI system is the proper demand model to be utilized in further empirical welfare analysis. Third, we find that unobserved provincial heterogeneity has significant effects on food consumption patterns in Russia. Fourth, the results from the Durbin-Wu-Hausman test show that food commodity prices are endogenous and, unless accounted for, would lead to inconsistent estimates of demand parameters. Finally, we estimate the complete system of the GEASI demand and reduced-form price equations with 55 different time transition structures $(h)$ and find that $h=8$ provides the best fit of the data based on the Akaike information criterion (Akaike, 1974). This is most consistent with the hypothesis that consumers underwent structural preference change that began in 2007 and lasted until 2014.

To shed light on the effects of the restrictive assumptions examined above, we evaluate the effect on own-price and income elasticity of demand resulting of the omission of (i) precommitted demand; ( $i$ ) regional fixed-effects, and (iii) supply side of the agricultural commodity price determination mechanism. As can be observed from online supplementary appendix, the own-price and income elasticity differences appear to be statistically and economically significant for a majority of food commodities in our sample. Therefore, future studies should take advantage of these flexible modeling strategies, especially when analyzing various policies concerning such important aspects of economies as food consumption, population health, foreign trade, and food security.

Table 3 presents the demand parameter estimates from the full model. Importantly, precommitted demand is found to be positive and statistically significant for meats $(24.8 \mathrm{~kg}$ or $36.7 \%$ total meat consumption), cereals ( $72.1 \mathrm{~kg}$ or $60.4 \%$ total cereal consumption), and vegetable

\footnotetext{
${ }^{9}$ See Dhar, Chavas, and Gould (2003) for more details on the advantages of using the FIML procedure.

${ }^{10}$ The degree of polynomial functions estimated cannot exceed 7 (i.e., $R<N$ ), otherwise the resulting Engel curves will be arbitrarily complex, and the model may not converge (Lewbel and Pendakur, 2009).
} 
Table 2. Summary of the model diagnostic tests

\begin{tabular}{|c|c|c|c|}
\hline Main Hypotheses & $\begin{array}{l}\text { Likelihood Ratio } \\
\text { Value }\end{array}$ & $d f$ & $\begin{array}{c}P \\
\text { values }\end{array}$ \\
\hline \multicolumn{4}{|l|}{ Model specification tests } \\
\hline (i) Linear vs. quadratic Engel curves (i.e., $\beta_{i 2}=0, \forall i=1, \ldots, N$ ) & 46.20 & 8 & 0.00 \\
\hline (ii) Quadratic vs. cubic Engel curves (i.e., $\beta_{i 3}=0, \forall i=1, \ldots, N$ ) & 42.20 & 8 & 0.00 \\
\hline (iii) Cubic vs. quartic Engel curves (i.e., $\beta_{i 4}=0, \forall i=1, \ldots, N$ ) & 42.60 & 8 & 0.00 \\
\hline (iv) Quartic vs. quintic Engel curves (i.e., $\beta_{i 5}=0, \forall i=1, \ldots, N$ ) & 12.70 & 8 & 12.26 \\
\hline $\begin{array}{l}\text { Commodities are not consumed in pre-committed quantities } \\
\text { ( } c_{j}=0, \forall j=1, \ldots, n \text { or GEASI and EASI are equivalent) }\end{array}$ & 282.2 & 8 & 0.00 \\
\hline $\begin{array}{l}\text { Unobserved provincial heterogeneity has significant impacts on food } \\
\text { consumption (FE vs. no FE) }\end{array}$ & $1,329.6$ & 176 & 0.00 \\
\hline \multirow[t]{2}{*}{ Food commodity prices are exogenous } & 157.4 & 56 & 0.00 \\
\hline & \multicolumn{3}{|c|}{ Structural change period } \\
\hline Optimal $h$ structure & \multicolumn{3}{|c|}{$\tau_{1}=2007, \tau_{2}=2014$} \\
\hline
\end{tabular}

Note: The GEASI specifications are estimated on household food expenditure panel data obtained from the FSSS of Russian Federation. The data cover 67 oblasts/administrative units over the period 2006-2016 and include 7 widely consumed food commodity groups and a numeraire good (i.e., the remaining food and non-food items). A total of 5,896 observations have been utilized in the demand system estimation.

oils (5.3 kg or $42.4 \%$ total vegetable oil consumption). These results indicate the lack of Russian consumer flexibility when purchasing these food commodities (in the same vein, consumers appear to be relatively more responsive to income and price changes when purchasing the remaining commodities). Additionally, time variable parameter estimates are insignificant for precommitted demand across all the equations, which suggests that this demand component has not been subject to structural preference change over our sample period. Table 4 provides the parameter estimates from the reduced-form price equations. It can be seen that many estimates are statistically significant and are compatible with supply side effects on prices. For example, higher temperatures are found to have negative effects on food prices due probably to their favorable effects on crop production.

Tables 5 and 6 report the Marshallian, Income and Hicksian elasticity estimates, all of which appear to be consistent with consumer theory. Specifically, Marshallian own-price elasticity estimates are negative, statistically significant, and fall in the range of -1.11 for fats/oil to -0.88 for dairy, pointing to the fact that despite the lack of substitutes for these aggregately defined food commodities, Russian consumers are generally price-sensitive. Our own-price elasticities of demand for cereals $(-1.11)$ and dairy $(-0.88)$ are similar to those provided in other studies (e.g., Burggraf et al., 2015; Hovhannisyan and Shanoyan, 2019; Staudigel and Schröck, 2015). However, our own-price elasticity for meats $(-1.03)$ is larger in absolute value vis-à-vis the respective estimates in Goodwin et al. (2002), Staudigel and Schröck (2015), and Hovhannisyan and Shanoyan (2019), due perhaps to our inclusion of pre-committed consumption and addressing of price endogeneity. Our income elasticity varies from 0.62 for dairy to 1.05 for other food and non-food products and services, which agrees with the Engel's law and the findings from Zhen et al. (2013). Income elasticity for meats (0.833) is similar to that in Hovhannisyan and Shanoyan (2019). However, our estimate is considerably higher than that in Goodwin et al. (2002). ${ }^{11}$

\footnotetext{
${ }^{11}$ The remaining studies that we are familiar with report only expenditure elasticities, which are not directly comparable with our income elasticity estimates.
} 
Table 3. Parameter estimates from the GEASI expenditure share equations

\begin{tabular}{|c|c|c|c|c|c|c|c|c|}
\hline Parameter & Meats & Veg. & Cereals & Eggs & Fats/Oil & Sugar & Dairy & Other \\
\hline \multirow[t]{2}{*}{ Pre-committed demand $\left(c_{i 0}\right)$} & $24.802^{a}$ & 0.000 & $72.081^{a}$ & 31.890 & $5.347^{\mathrm{a}}$ & 0.000 & 16.373 & 0.000 \\
\hline & $(10.271)$ & (17.115) & (21.111) & $(35.302)$ & $(1.597)$ & $(6.567)$ & (27.147) & $(54.461)$ \\
\hline \multirow[t]{2}{*}{ Pre-committed demand $\left(c_{i 1}^{h}\right)$} & -0.089 & 0.122 & 0.048 & -0.027 & 0.009 & 0.002 & 0.020 & 3.147 \\
\hline & $(0.222)$ & $(0.106)$ & $(0.106)$ & $(0.021)$ & $(0.019)$ & $(0.080)$ & (0.092) & (2.733) \\
\hline \multirow[t]{2}{*}{ Intercept $\left(\beta_{i 0}\right)$} & $0.063^{\mathrm{a}}$ & $0.022^{\mathrm{a}}$ & $0.031^{\mathrm{a}}$ & $0.004^{\mathrm{a}}$ & $0.004^{\mathrm{a}}$ & $0.014^{\mathrm{a}}$ & $0.030^{\mathrm{a}}$ & $0.830^{\mathrm{a}}$ \\
\hline & $(0.001)$ & $(0.000)$ & $(0.001)$ & $(0.000)$ & $(0.000)$ & $(0.000)$ & $(0.000)$ & $(0.000)$ \\
\hline \multirow[t]{2}{*}{ Intercept $\left(\beta_{i 0}^{h}\right)$} & $0.004^{a}$ & 0.000 & 0.001 & 0.000 & 0.000 & 0.000 & $0.003^{a}$ & $0.002^{a}$ \\
\hline & $(0.001)$ & $(0.001)$ & $(0.001)$ & $(0.000)$ & $(0.000)$ & $(0.000)$ & $(0.000)$ & $(0.000)$ \\
\hline \multirow[t]{2}{*}{ Real income $\left(\beta_{i 10}\right)$} & $-0.104^{a}$ & $-0.084^{a}$ & $-0.054^{a}$ & $-0.014^{\mathrm{a}}$ & $-0.008^{a}$ & $-0.045^{a}$ & $-0.118^{\mathrm{a}}$ & $-0.038^{a}$ \\
\hline & $(0.021)$ & $(0.023)$ & $(0.000)$ & $(0.002)$ & $(0.002)$ & $(0.003)$ & $(0.001)$ & $(0.005)$ \\
\hline \multirow[t]{2}{*}{ Real income $\left(\beta_{i 11}^{h}\right)$} & 0.052 & 0.019 & 0.026 & 0.003 & 0.003 & 0.012 & 0.020 & $0.036^{a}$ \\
\hline & $(0.041)$ & $(0.017)$ & $(0.020)$ & $(0.002)$ & $(0.002)$ & $(0.011)$ & $(0.018)$ & $(0.018)$ \\
\hline \multirow[t]{2}{*}{ Real income $\left(\beta_{i 20}\right)$} & 0.002 & 0.001 & 0.005 & 0.000 & $0.001^{a}$ & $0.002^{\mathrm{a}}$ & 0.010 & $0.020^{\mathrm{a}}$ \\
\hline & $(0.011)$ & $(0.001)$ & $(0.004)$ & $(0.000)$ & $(0.000)$ & $(0.001)$ & $(0.007)$ & $(0.007)$ \\
\hline \multirow[t]{2}{*}{ Real income $\left(\beta_{i 21}^{h}\right)$} & 0.009 & 0.004 & $0.004^{a}$ & 0.001 & 0.001 & 0.003 & 0.004 & $0.007^{a}$ \\
\hline & $(0.008)$ & $(0.004)$ & $(0.001)$ & $(0.001)$ & $(0.001)$ & $(0.002)$ & $(0.003)$ & $(0.003)$ \\
\hline \multirow[t]{2}{*}{ Real income $\left(\beta_{i 30}\right)$} & -0.004 & -0.001 & $-0.003^{a}$ & 0.000 & $-0.001^{a}$ & -0.001 & $-0.004^{a}$ & $-0.004^{a}$ \\
\hline & $(0.003)$ & $(0.001)$ & $(0.001)$ & $(0.000)$ & $(0.000)$ & $(0.001)$ & $(0.001)$ & $(0.001)$ \\
\hline \multirow[t]{2}{*}{ Real income $\left(\beta_{i 31}^{h}\right)$} & 0.005 & 0.002 & 0.002 & 0.000 & 0.000 & 0.001 & 0.002 & 0.001 \\
\hline & $(0.005)$ & $(0.002)$ & $(0.002)$ & $(0.000)$ & $(0.000)$ & $(0.001)$ & $(0.002)$ & $(0.001)$ \\
\hline \multirow[t]{2}{*}{ Real income $\left(\beta_{i 40}\right)$} & $0.002^{a}$ & 0.000 & 0.000 & 0.000 & $0.000^{\mathrm{a}}$ & 0.000 & 0.000 & $0.001^{a}$ \\
\hline & $(0.001)$ & $(0.000)$ & $(0.000)$ & $(0.000)$ & $(0.000)$ & $(0.000)$ & $(0.000)$ & $(0.000)$ \\
\hline \multirow[t]{2}{*}{ Real income $\left(\beta_{i 41}^{h}\right)$} & 0.002 & 0.001 & 0.001 & 0.000 & 0.000 & 0.001 & 0.001 & 0.001 \\
\hline & $(0.001)$ & $(0.001)$ & $(0.001)$ & $(0.000)$ & $(0.000)$ & $(0.000)$ & $(0.001)$ & $(0.001)$ \\
\hline \multirow[t]{2}{*}{ Price $\left(\alpha_{i 10}\right)$ meats } & -0.026 & $0.024^{a}$ & $0.021^{a}$ & $0.006^{a}$ & $0.003^{a}$ & $0.026^{a}$ & -0.003 & -0.050 \\
\hline & $(0.034)$ & $(0.004)$ & $(0.005)$ & $(0.001)$ & $(0.001)$ & $(0.003)$ & $(0.004)$ & $(0.042)$ \\
\hline \multirow[t]{2}{*}{ Price $\left(\alpha_{i 11}^{h}\right)$ meats } & 0.006 & -0.002 & 0.002 & $0.000^{\mathrm{a}}$ & 0.001 & -0.001 & 0.000 & -0.007 \\
\hline & $(0.027)$ & $(0.004)$ & $(0.004)$ & $(0.000)$ & $(0.001)$ & $(0.002)$ & $(0.004)$ & $(0.032)$ \\
\hline \multirow[t]{2}{*}{ Price $\left(\alpha_{i 20}\right)$ veg. } & & 0.010 & $0.026^{a}$ & -0.001 & $-0.003^{a}$ & 0.002 & $0.018^{a}$ & $-0.075^{a}$ \\
\hline & & $(0.015)$ & $(0.002)$ & $(0.001)$ & $(0.001)$ & $(0.002)$ & $(0.003)$ & $(0.015)$ \\
\hline \multirow[t]{2}{*}{ Price $\left(\alpha_{i 21}^{h}\right)$ veg. } & & -0.015 & -0.001 & 0.000 & 0.000 & 0.001 & 0.001 & 0.016 \\
\hline & & $(0.014)$ & $(0.003)$ & $(0.001)$ & $(0.001)$ & $(0.002)$ & $(0.003)$ & $(0.014)$ \\
\hline \multirow[t]{2}{*}{ Price $\left(\alpha_{i 30}\right)$ cereals } & & & -0.038 & $0.011^{a}$ & $0.006^{a}$ & 0.002 & $0.019^{a}$ & $-0.048^{a}$ \\
\hline & & & $(0.021)$ & $(0.001)$ & $(0.001)$ & $(0.002)$ & $(0.004)$ & $(0.021)$ \\
\hline \multirow[t]{2}{*}{ Price $\left(\alpha_{i 31}^{h}\right)$ cereals } & & & -0.010 & 0.001 & $-0.002^{\mathrm{a}}$ & 0.001 & 0.002 & 0.007 \\
\hline & & & $(0.017)$ & $(0.001)$ & $(0.001)$ & $(0.002)$ & $(0.004)$ & $(0.017)$ \\
\hline
\end{tabular}


Table 3. (Continued)

\begin{tabular}{|c|c|c|c|c|c|c|c|c|}
\hline Parameter & Meats & Veg. & Cereals & Eggs & Fats/Oil & Sugar & Dairy & Other \\
\hline \multirow[t]{2}{*}{ Price $\left(\alpha_{i 40}\right)$ eggs } & & & & 0.000 & 0.000 & -0.002 & -0.002 & $-0.012^{\mathrm{a}}$ \\
\hline & & & & $(0.002)$ & $(0.000)$ & $(0.001)$ & $(0.001)$ & $(0.002)$ \\
\hline \multirow[t]{2}{*}{ Price $\left(\alpha_{i 41}^{h}\right)$ eggs } & & & & -0.001 & 0.000 & 0.000 & 0.000 & 0.001 \\
\hline & & & & $(0.002)$ & $(0.000)$ & $(0.001)$ & $(0.001)$ & $(0.002)$ \\
\hline \multirow[t]{2}{*}{ Price $\left(\alpha_{i 50}\right)$ fats/oil } & & & & & $-0.005^{a}$ & 0.001 & $0.005^{\mathrm{a}}$ & $-0.008^{a}$ \\
\hline & & & & & $(0.002)$ & $(0.001)$ & $(0.001)$ & $(0.002)$ \\
\hline \multirow[t]{2}{*}{ Price $\left(\alpha_{i 51}^{h}\right)$ fats/oil } & & & & & -0.001 & 0.000 & -0.001 & 0.002 \\
\hline & & & & & $(0.001)$ & $(0.001)$ & $(0.001)$ & $(0.002)$ \\
\hline \multirow[t]{2}{*}{ Price $\left(\alpha_{i 60}\right)$ sugar } & & & & & & -0.002 & $0.007^{\mathrm{a}}$ & $-0.034^{\mathrm{a}}$ \\
\hline & & & & & & $(0.010)$ & $(0.003)$ & $(0.010)$ \\
\hline \multirow[t]{2}{*}{ Price $\left(\alpha_{i 61}^{h}\right)$ sugar } & & & & & & 0.003 & -0.003 & -0.001 \\
\hline & & & & & & $(0.010)$ & $(0.003)$ & (0.009) \\
\hline \multirow[t]{2}{*}{ Price $\left(\alpha_{i 70}\right)$ dairy } & & & & & & & 0.032 & $-0.076^{\mathrm{a}}$ \\
\hline & & & & & & & $(0.022)$ & $(0.016)$ \\
\hline \multirow[t]{2}{*}{ Price $\left(\alpha_{i 11}^{h}\right)$ dairy } & & & & & & & $-0.008^{a}$ & 0.008 \\
\hline & & & & & & & $(0.000)$ & $(0.015)$ \\
\hline \multirow[t]{2}{*}{ Price $\left(\alpha_{i 80}\right)$ other } & & & & & & & & 0.007 \\
\hline & & & & & & & & $(0.027)$ \\
\hline \multirow[t]{2}{*}{ Price $\left(\alpha_{i s 1}^{h}\right)$ other } & & & & & & & & $0.012^{\mathrm{a}}$ \\
\hline & & & & & & & & $(0.006)$ \\
\hline
\end{tabular}

$\mathrm{a}, \mathrm{b}, \mathrm{c}$ Parameter estimates that are statistically different from 0 at the $0.01,0.05$, and 0.10 significance levels, respectively.

Note: The standard errors are in parenthesis.

To examine the effects of structural food preference change on the elasticity estimates, we use paired $t$-test of difference to compute the change in Marshallian price elasticity estimates over the span of 2006-2015 (Table 7). Our findings indicate that all Marshallian price effects have undergone significant changes, with a majority of own-price estimates having increased in magnitude (i.e., became more negative). We further compute provincial-level income and price elasticities to illustrate the effects of structural preference change across commodities and provinces. The income elasticity estimates graphically presented for select commodities such as vegetables (Figure 1, Panel A) and meats (Figure 1, Panel B) may be indicative of vegetables having gained popularity as is evidenced by the rising magnitude of the respective income elasticities of demand, while consumer preferences for meat products (and cereals, as can be seen in Figure 2) have declined in the majority of the provinces in our sample, suggesting perhaps consumer saturation in these food categories.

As a final exercise, we evaluate consumer welfare effects of actual food price changes in Russia over our sample period, with allowance made for structural food preference changes. This analysis is important, given that the rapid rise in food prices brought by global commodity price spikes over 2006-2008 adversely affected a number of countries and created serious welfare concerns among the population segments most vulnerable to food price volatility (Attanasio et al., 2013). 
Table 4. Parameter estimates from the reduced-price equations

\begin{tabular}{|c|c|c|c|c|c|c|c|c|}
\hline Commodity & Meats & Veg. & Cereals & Eggs & Fats/Oil & Sugar & Dairy & Other \\
\hline \multirow[t]{2}{*}{ January rainfall $\left(\mu_{i 1}\right)$} & 0.054 & $0.170^{\mathrm{a}}$ & 0.089 & 0.045 & 0.040 & 0.037 & 0.059 & -0.058 \\
\hline & $(0.044)$ & $(0.042)$ & $(0.042)$ & $(0.052)$ & $(0.064)$ & $(0.043)$ & $(0.039)$ & $(0.049)$ \\
\hline \multirow[t]{2}{*}{ July rainfall $\left(\mu_{i 2}\right)$} & 0.054 & 0.025 & $0.097^{b}$ & 0.043 & $0.113^{c}$ & 0.055 & $0.112^{\mathrm{a}}$ & $-0.129^{a}$ \\
\hline & $(0.039)$ & $(0.042)$ & $(0.041)$ & $(0.050)$ & $(0.057)$ & $(0.042)$ & $(0.042)$ & $(0.040)$ \\
\hline \multirow[t]{2}{*}{ January temperature $\left(\mu_{i 3}\right)$} & $-0.122^{b}$ & $-0.267^{a}$ & $-0.124^{a}$ & $-0.182^{a}$ & $-0.179^{a}$ & $-0.249^{a}$ & $-0.128^{a}$ & $0.319^{a}$ \\
\hline & $(0.051)$ & $(0.048)$ & $(0.051)$ & $(0.066)$ & $(0.069)$ & $(0.054)$ & $(0.047)$ & $(0.056)$ \\
\hline \multirow{2}{*}{ July temperature $\left(\mu_{i 4}\right)$} & -0.047 & $-0.232^{a}$ & $-0.156^{a}$ & $-0.165^{a}$ & 0.014 & $-0.118^{b}$ & -0.044 & $-0.148^{a}$ \\
\hline & $(0.051)$ & $(0.045)$ & $(0.048)$ & $(0.057)$ & $(0.067)$ & $(0.050)$ & $(0.047)$ & $(0.052)$ \\
\hline \multirow[t]{2}{*}{ Gas emissions $\left(\mu_{i 5}\right)$} & -0.045 & 0.097 & -0.061 & -0.163 & 0.014 & -0.055 & 0.017 & -0.005 \\
\hline & $(0.090)$ & $(0.068)$ & $(0.087)$ & $(0.104)$ & $(0.092)$ & $(0.089)$ & $(0.102)$ & $(0.065)$ \\
\hline \multirow[t]{2}{*}{ Polluted water $\left(\mu_{i 6}\right)$} & -0.088 & 0.133 & 0.043 & -0.101 & -0.125 & -0.052 & 0.019 & -0.005 \\
\hline & $(0.069)$ & $(0.070)$ & $(0.081)$ & $(0.090)$ & $(0.097)$ & $(0.082)$ & $(0.077)$ & $(0.064)$ \\
\hline \multirow[t]{2}{*}{ Per capita ag. land $\left(\mu_{i 7}\right)$} & 0.050 & -0.018 & 0.005 & -0.136 & $-0.245^{a}$ & 0.081 & $-0.161^{a}$ & 0.019 \\
\hline & $(0.055)$ & $(0.050)$ & $(0.053)$ & $(0.089)$ & $(0.061)$ & $(0.055)$ & $(0.055)$ & $(0.062)$ \\
\hline \multirow[t]{2}{*}{ Freshwater supply $\left(\mu_{i 8}\right)$} & $0.149^{c}$ & $-0.213^{a}$ & -0.092 & 0.029 & 0.038 & 0.058 & 0.026 & -0.043 \\
\hline & $(0.069)$ & $(0.062)$ & $(0.068)$ & $(0.076)$ & $(0.074)$ & $(0.071)$ & $(0.067)$ & (0.053) \\
\hline
\end{tabular}

$\mathrm{a}, \mathrm{b}, \mathrm{c}$ Parameter estimates that are statistically different from 0 at the $0.01,0.05$, and 0.10 significance levels, respectively.

Note: The standard errors are in parenthesis.

Table 5. Marshallian price and income elasticity estimates from the GEASI system

\begin{tabular}{lccccccccc}
\hline Commodity & Meats & Veg. & Cereals & Eggs & Fats/Oil & Sugar & Dairy & Other & Income \\
\hline Meats & $-1.032^{\mathrm{a}}$ & $0.041^{\mathrm{a}}$ & $0.040^{\mathrm{a}}$ & $0.010^{\mathrm{a}}$ & $0.006^{\mathrm{a}}$ & $0.043^{\mathrm{a}}$ & 0.000 & $0.059^{\mathrm{a}}$ & $0.833^{\mathrm{a}}$ \\
\hline & $(0.058)$ & $(0.006)$ & $(0.007)$ & $(0.001)$ & $(0.001)$ & $(0.005)$ & $(0.007)$ & $(0.015)$ & $(0.084)$ \\
\hline Veg. & $0.128^{\mathrm{a}}$ & $-0.949^{\mathrm{a}}$ & $0.127^{\mathrm{a}}$ & -0.003 & $-0.014^{\mathrm{a}}$ & $0.016^{\mathrm{b}}$ & $0.092^{\mathrm{a}}$ & $-0.024^{\mathrm{c}}$ & $0.626^{\mathrm{a}}$ \\
\hline & $(0.017)$ & $(0.069)$ & $(0.011)$ & $(0.003)$ & $(0.003)$ & $(0.008)$ & $(0.013)$ & $(0.016)$ & $(0.083)$ \\
\hline Cereals & $0.078^{\mathrm{a}}$ & $0.085^{\mathrm{a}}$ & $-1.114^{\mathrm{a}}$ & $0.035^{\mathrm{a}}$ & $0.021^{\mathrm{a}}$ & 0.010 & $0.065^{\mathrm{a}}$ & -0.010 & $0.829^{\mathrm{a}}$ \\
\hline & $(0.013)$ & $(0.007)$ & $(0.069)$ & $(0.003)$ & $(0.003)$ & $(0.008)$ & $(0.013)$ & $(0.011)$ & $(0.084)$ \\
\hline Eggs & $0.158^{\mathrm{a}}$ & -0.014 & $0.268^{\mathrm{a}}$ & $-0.998^{\mathrm{a}}$ & -0.001 & $-0.035^{\mathrm{b}}$ & $-0.038^{\mathrm{b}}$ & -0.002 & $0.661^{\mathrm{a}}$ \\
\hline & $(0.018)$ & $(0.014)$ & $(0.023)$ & $(0.054)$ & $(0.009)$ & $(0.017)$ & $(0.017)$ & $(0.014)$ & $(0.068)$ \\
\hline Fats/oil & $0.102^{\mathrm{a}}$ & $-0.087^{\mathrm{a}}$ & $0.176^{\mathrm{a}}$ & -0.001 & $-1.122^{\mathrm{a}}$ & 0.018 & $0.150^{\mathrm{a}}$ & $-0.034^{\mathrm{c}}$ & $0.799^{\mathrm{a}}$ \\
\hline Sugar & $(0.023)$ & $(0.019)$ & $(0.027)$ & $(0.010)$ & $(0.040)$ & $(0.020)$ & $(0.023)$ & $(0.019)$ & $0.077)$ \\
\hline & $0.199^{\mathrm{a}}$ & $0.024^{\mathrm{b}}$ & 0.027 & $-0.010^{\mathrm{b}}$ & 0.005 & $-1.010^{\mathrm{a}}$ & $0.059^{\mathrm{a}}$ & 0.021 & $0.685^{\mathrm{a}}$ \\
\hline Dairy & $(0.020)$ & $(0.012)$ & $(0.017)$ & $(0.005)$ & $(0.005)$ & $(0.074)$ & $(0.019)$ & $(0.016)$ & $(0.085)$ \\
\hline & 0.014 & $0.067^{\mathrm{a}}$ & $0.074^{\mathrm{a}}$ & $-0.005^{\mathrm{b}}$ & $0.019^{\mathrm{a}}$ & $0.029^{\mathrm{a}}$ & $-0.884^{\mathrm{a}}$ & $0.071^{\mathrm{a}}$ & $0.615^{\mathrm{a}}$ \\
\hline & $(0.014)$ & $(0.009)$ & $(0.014)$ & $(0.002)$ & $(0.003)$ & $(0.009)$ & $(0.073)$ & $(0.012)$ & $(0.067)$ \\
\hline Other & -0.009 & $-0.010^{\mathrm{a}}$ & $-0.007^{\mathrm{a}}$ & $-0.002^{\mathrm{b}}$ & -0.001 & $-0.005^{\mathrm{a}}$ & $-0.011^{\mathrm{a}}$ & $-1.006^{\mathrm{a}}$ & $1.052^{\mathrm{a}}$ \\
\hline & $(0.006)$ & $(0.002)$ & $(0.003)$ & $(0.000)$ & $(0.000)$ & $(0.001)$ & $(0.002)$ & $(0.042$ & $(0.010)$ \\
\hline
\end{tabular}

a,b,c Parameter estimates that are statistically different from 0 at the $0.01,0.05$, and 0.10 significance levels, respectively. Notes: The standard errors are in parenthesis. The first column represents commodities with price change. 
Table 6. Hicksian elasticity estimates from the GEASI system

\begin{tabular}{|c|c|c|c|c|c|c|c|c|}
\hline Commodity & Meats & Veg. & Cereals & Eggs & Fats/Oil & Sugar & Dairy & Other \\
\hline \multirow[t]{2}{*}{ Meats } & $-0.980^{\mathrm{a}}$ & $0.060^{\mathrm{a}}$ & $0.066^{a}$ & $0.013^{\mathrm{a}}$ & $0.009^{a}$ & $0.055^{\mathrm{a}}$ & $0.026^{a}$ & $0.750^{\mathrm{a}}$ \\
\hline & $(0.054)$ & $(0.006)$ & $(0.007)$ & $(0.001)$ & $(0.001)$ & $(0.005)$ & $(0.007)$ & $(0.067)$ \\
\hline \multirow[t]{2}{*}{ Veg. } & $0.167^{a}$ & $-0.935^{a}$ & $0.147^{a}$ & 0.000 & $-0.012^{a}$ & $0.025^{a}$ & $0.111^{a}$ & $0.496^{a}$ \\
\hline & $(0.018)$ & $(0.067)$ & $(0.011)$ & $(0.003)$ & $(0.003)$ & $(0.007)$ & $(0.013)$ & $(0.067)$ \\
\hline \multirow[t]{2}{*}{ Cereals } & $0.130^{\mathrm{a}}$ & $0.104^{a}$ & $-1.087^{a}$ & $0.038^{a}$ & $0.024^{a}$ & $0.022^{\mathrm{a}}$ & $0.090^{\mathrm{a}}$ & $0.679^{a}$ \\
\hline & $(0.015)$ & $(0.008)$ & $(0.067)$ & $(0.003)$ & $(0.003)$ & $(0.008)$ & $(0.014)$ & $(0.068)$ \\
\hline \multirow[t]{2}{*}{ Eggs } & $0.199^{a}$ & 0.001 & $0.289^{a}$ & $-0.995^{\mathrm{a}}$ & 0.002 & -0.026 & -0.017 & $0.547^{a}$ \\
\hline & $(0.019)$ & $(0.014)$ & $(0.023)$ & $(0.054)$ & $(0.009)$ & $(0.017)$ & $(0.017)$ & $(0.056)$ \\
\hline \multirow[t]{2}{*}{ Fats/oil } & $0.152^{\mathrm{a}}$ & $-0.069^{a}$ & $0.201^{\mathrm{a}}$ & 0.002 & $-1.119^{a}$ & 0.029 & $0.175^{\mathrm{a}}$ & $0.629^{a}$ \\
\hline & $(0.024)$ & $(0.019)$ & $(0.027)$ & $(0.010)$ & $(0.040)$ & $(0.020)$ & $(0.023)$ & $(0.061)$ \\
\hline \multirow[t]{2}{*}{ Sugar } & $0.242^{\mathrm{a}}$ & $0.039^{a}$ & $0.049^{a}$ & $-0.008^{c}$ & $0.008^{c}$ & $-1.000^{a}$ & $0.080^{a}$ & $0.590^{a}$ \\
\hline & $(0.021)$ & $(0.012)$ & $(0.017)$ & $(0.005)$ & $(0.005)$ & $(0.074)$ & $(0.019)$ & $(0.068)$ \\
\hline \multirow[t]{2}{*}{ Dairy } & $0.052^{a}$ & $0.081^{a}$ & $0.093^{a}$ & -0.002 & $0.022^{a}$ & $0.037^{a}$ & $-0.865^{a}$ & $0.582^{a}$ \\
\hline & $(0.015)$ & $(0.009)$ & $(0.014)$ & $(0.002)$ & $(0.003)$ & $(0.009)$ & $(0.072)$ & $(0.053)$ \\
\hline \multirow[t]{2}{*}{ Other } & $0.057^{\mathrm{a}}$ & $0.013^{a}$ & $0.026^{a}$ & $0.003^{a}$ & $0.003^{a}$ & $0.010^{a}$ & $0.022^{\mathrm{a}}$ & $-0.133^{a}$ \\
\hline & $(0.005)$ & $(0.002)$ & $(0.003)$ & $(0.000$ & $(0.000)$ & $(0.001)$ & $(0.002)$ & (0.042) \\
\hline
\end{tabular}

$a, b, c$ Parameter estimates that are statistically different from 0 at the $0.01,0.05$, and 0.10 significance levels, respectively. Notes: The standard errors are in parenthesis. The first column represents commodities with price change.

We perform this computation for all the provinces under study based on the compensating variation $(\mathrm{CV})$ method that utilizes compensated elasticity estimates obtained from our empirical framework, as well as the actual food price changes for the seven food aggregates. Online supplementary appendix reveals that the per capita average annual CV estimates range from 2,500 Rubles (about \$83) for Tambov to 7,000 Rubles (about \$233) for Magadan, indicating a welfare loss that an average Russian consumer has undergone annually over 2006-2016. When extrapolated to the entire sample period of 11 years, these estimates are equivalent to $\$ 913$ for Tambov and \$2,563 for Magadan, computed on a per capita basis. We further evaluate the difference in the estimates of the welfare consequences of actual price changes in the country, as well as those of hypothetical scenarios of $15 \%$ and $25 \%$ uniform price increases, resulting from ignoring food preference changes. The respective $\mathrm{CV}$ estimates are found to be positive under both frameworks that ignore and address structural food preference transition, which is indicative of welfare loss. We find that disregarding preference dynamics overstates the welfare loss by $\$ 37$ million for the actual price changes, and by $\$ 46$ million and $\$ 77$ million for the simulated uniform price increase by $15 \%$ and $25 \%$, respectively. ${ }^{12}$ These estimates further illustrate the importance of understanding potential food preference changes in Russia.

\footnotetext{
${ }^{12}$ It is important to note that the calculations of welfare impacts and the effects of various restrictive assumptions are based on only the seven food commodities analyzed, given our focus on consumer food preferences. We expect the magnitudes of these estimates to be considerably larger should the numeraire good be incorporated into the assessment of welfare effects.
} 
Table 7. Change in Marshallian price elasticity estimates induced by preference change

\begin{tabular}{|c|c|c|c|c|c|c|c|c|}
\hline Commodity & Meats & Veg. & Cereals & Eggs & Fats/Oil & Sugar & Dairy & Other \\
\hline \multirow[t]{2}{*}{ Meats } & $-0.084^{a}$ & $0.001^{\mathrm{a}}$ & $0.013^{a}$ & $0.002^{\mathrm{a}}$ & $0.003^{a}$ & $-0.014^{\mathrm{a}}$ & $-0.037^{\mathrm{a}}$ & ${ }^{\mathrm{a}} 0.163$ \\
\hline & $(0.002)$ & $(0.000)$ & $(0.000)$ & $(0.000)$ & $(0.000)$ & $(0.000)$ & $(0.000)$ & $(0.001)$ \\
\hline \multirow[t]{2}{*}{ Veg. } & ${ }^{\mathrm{a}} 0.002$ & $-0.014^{a}$ & $-0.027^{a}$ & $-0.008^{\mathrm{a}}$ & $-0.010^{a}$ & $-0.001^{a}$ & $0.038^{\mathrm{a}}$ & $0.055^{\mathrm{a}}$ \\
\hline & $(0.001)$ & $(0.003)$ & $(0.001)$ & $(0.000)$ & $(0.000)$ & $(0.000)$ & $(0.001)$ & $(0.001)$ \\
\hline \multirow[t]{2}{*}{ Cereals } & $0.026^{\mathrm{a}}$ & $-0.018^{a}$ & $0.034^{\mathrm{a}}$ & $-0.002^{a}$ & $0.005^{a}$ & $-0.030^{\mathrm{a}}$ & $-0.066^{a}$ & ${ }^{\mathrm{a}} 0.117$ \\
\hline & $(0.001)$ & $(0.000)$ & $(0.003)$ & $(0.000)$ & $(0.000)$ & $(0.000)$ & $(0.001)$ & $(0.000)$ \\
\hline \multirow[t]{2}{*}{ Eggs } & $0.030^{\mathrm{a}}$ & $-0.040^{\mathrm{a}}$ & $-0.012^{\mathrm{a}}$ & $-0.007^{a}$ & $0.027^{a}$ & $-0.005^{a}$ & $-0.045^{a}$ & $0.115^{\mathrm{a}}$ \\
\hline & $(0.001)$ & $(0.001)$ & $(0.001)$ & $(0.002)$ & $(0.000)$ & $(0.001)$ & $(0.001)$ & $(0.001)$ \\
\hline \multirow[t]{2}{*}{ Fats/oil } & $0.046^{a}$ & $-0.058^{a}$ & $0.038^{a}$ & $0.030^{\mathrm{a}}$ & $-0.067^{a}$ & $-0.073^{a}$ & $-0.068^{a}$ & $0.101^{a}$ \\
\hline & $(0.001)$ & $(0.001)$ & $(0.001)$ & $(0.000)$ & $(0.002)$ & $(0.001)$ & $(0.001)$ & $(0.001)$ \\
\hline \multirow[t]{2}{*}{ Sugar } & $-0.061^{a}$ & $-0.001^{a}$ & $-0.067^{a}$ & $-0.002^{a}$ & $-0.019^{a}$ & $0.025^{a}$ & $0.079^{a}$ & $0.096^{a}$ \\
\hline & $(0.001)$ & $(0.001)$ & $(0.001)$ & $(0.000)$ & $(0.000)$ & $(0.003)$ & $(0.001)$ & $(0.001)$ \\
\hline \multirow[t]{2}{*}{ Dairy } & $-0.075^{a}$ & $0.028^{a}$ & $-0.069^{a}$ & $-0.006^{a}$ & $-0.008^{a}$ & $0.037^{a}$ & $-0.016^{a}$ & $0.166^{a}$ \\
\hline & $(0.001)$ & $(0.000)$ & $(0.001)$ & $(0.000)$ & $(0.000)$ & $(0.000)$ & $(0.003)$ & $(0.001)$ \\
\hline \multirow[t]{2}{*}{ Other } & $0.009^{a}$ & $0.000^{a}$ & $0.002^{\mathrm{a}}$ & $0.000^{\mathrm{a}}$ & $0.001^{a}$ & $0.001^{a}$ & $0.004^{\mathrm{a}}$ & $-0.027^{a}$ \\
\hline & $(0.000)$ & $(0.000)$ & $(0.000)$ & $(0.000)$ & $(0.000)$ & $(0.000)$ & $(0.000)$ & $(0.000)$ \\
\hline
\end{tabular}

a,b,c Parameter estimates that are statistically different from 0 at the $0.01,0.05$, and 0.10 significance levels, respectively. Notes: The standard errors are in parenthesis. The first column represents commodities with price change.

\section{Conclusions}

Following the disintegration of the Soviet Union, Russia underwent dramatic changes in its domestic food markets and the level of their integration with global agrifood systems. These events are widely believed to have reshaped tastes and preferences of Russian consumers, which may have been further impacted by the recent economic sanctions imposed by Russia on imports of agricultural products from western nations. While the importance of gaining a basic understanding of consumer preference dynamics in Russia is generally recognized, there has been a lack of studies in this research area mostly hampered by limited data.

In this study, we empirically examine the possible structural changes in Russian consumer food preferences using recent advances in consumer theory and the most current regional-level panel data on food consumption and agricultural commodity supply shifters. Specifically, we estimate a flexible demand system that not only accounts for regional fixed-effects but also addresses food price endogeneity that has been ignored in the previous literature. The main findings emerging from our study indicate that consumers underwent a structural food preference change that began in 2007 and continued into 2014. To illustrate the magnitude of this change, we contrast economic effects for select food commodities across the Russian provinces.

Our findings indicate that Russian consumers may have reached saturation in a number of food categories such as meats and cereals and may have developed an affinity for other products such as vegetables. Evidence also suggests that the recent economic restrictions may have further reduced the variety and quality of meat products in the country, which can have a dampening effect on meat consumption. Considering Russia's size as a meat-consuming country, currently accounting for 3.3\% of global meat consumption, there might be latent market opportunities that high-quality meat producers should monitor closely and be prepared to capture upon eventual reversal of sanctions by Russia and return to open trading regime. 


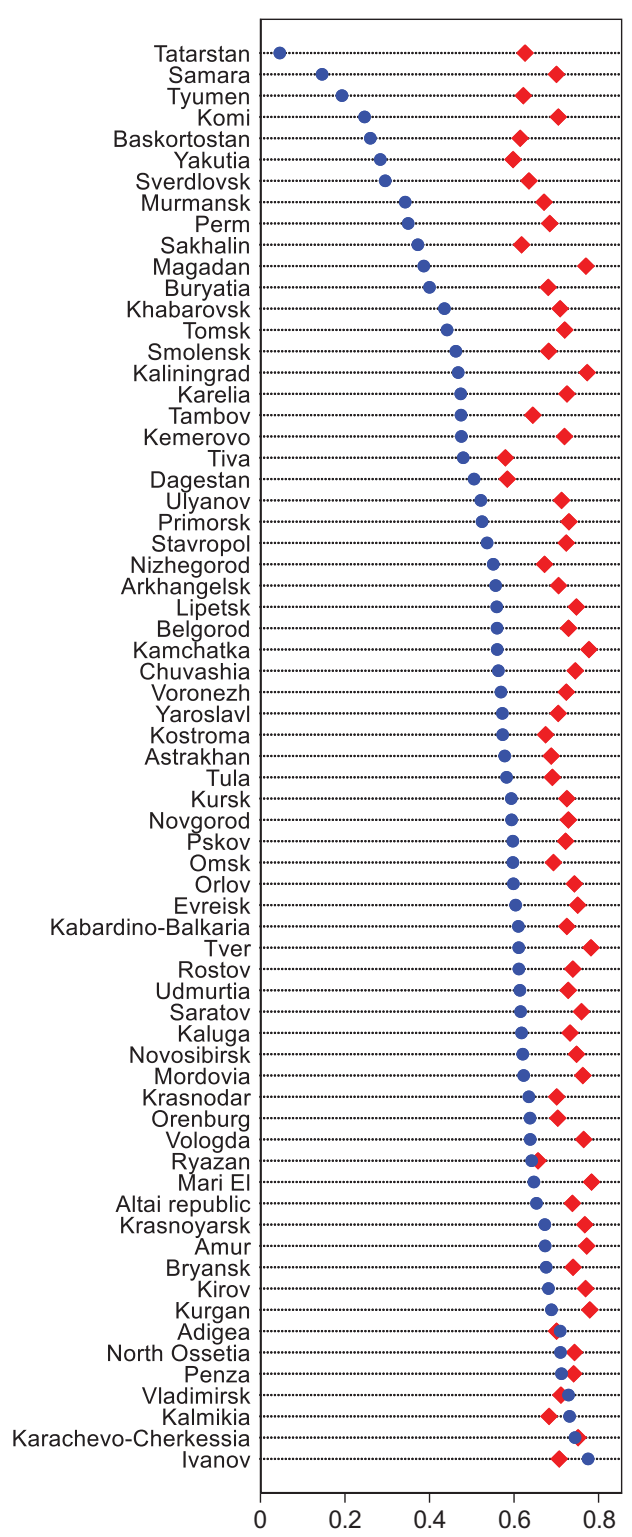

Panel A. Income elasticity of demand for vegetables

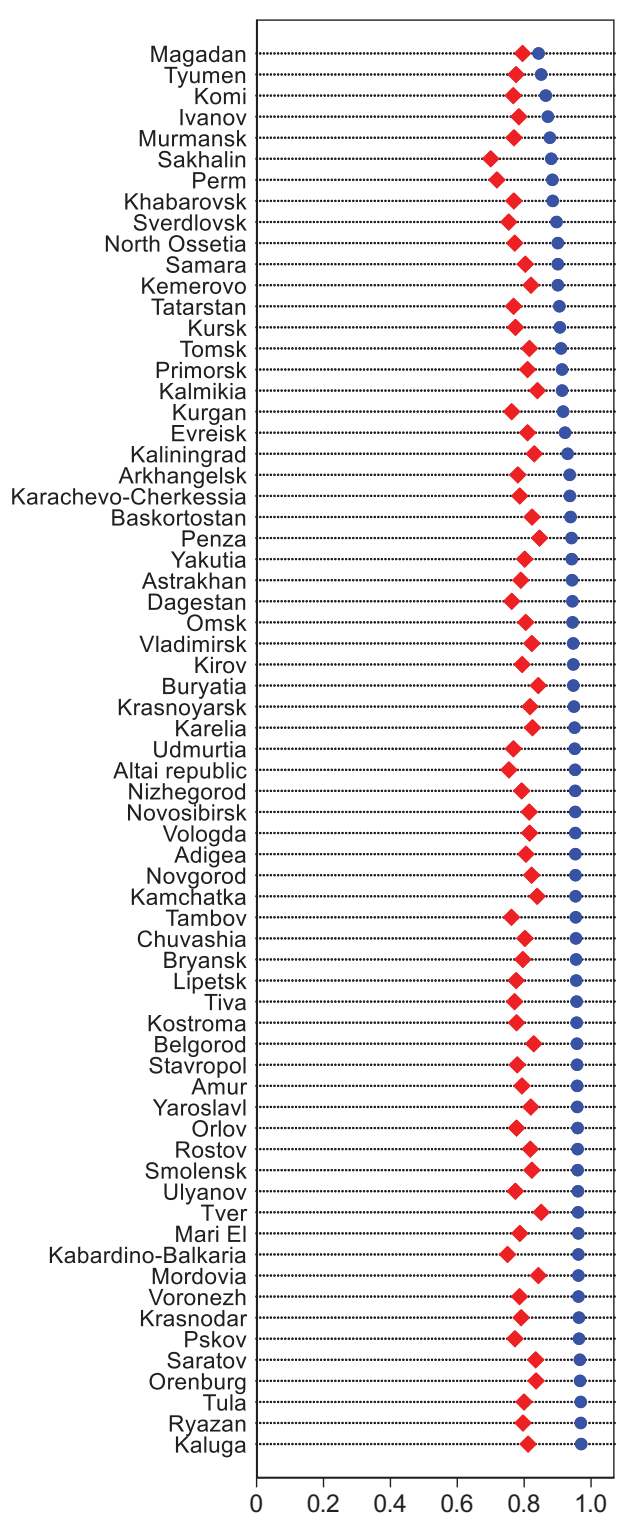

Panel B. Income elasticity of demand for meats

Figure 1. Provincial-level income elasticity of demand for vegetables and meats in 2006 and 2015.

Note: Elasticities for 2006 appear in blue, and those for 2015 are in red.

Opportunities also exist for high-value global vegetable producers to capitalize on the evergrowing Russian market in light of recent surge in demand for functional and organic foods known for their health benefits. Finally, following some of the recent fraudulent and counterfeiting practices in the dairy industry, imported dairy products attained popularity in Russia, thus creating export opportunities for the major dairy manufacturing companies and countries such as New Zealand, Germany, Netherlands, and Belgium.

We acknowledge that while we explore the possibility of structural preference changes, as well as assess the direction and magnitude of change, in this study we did not attempt to model the root 


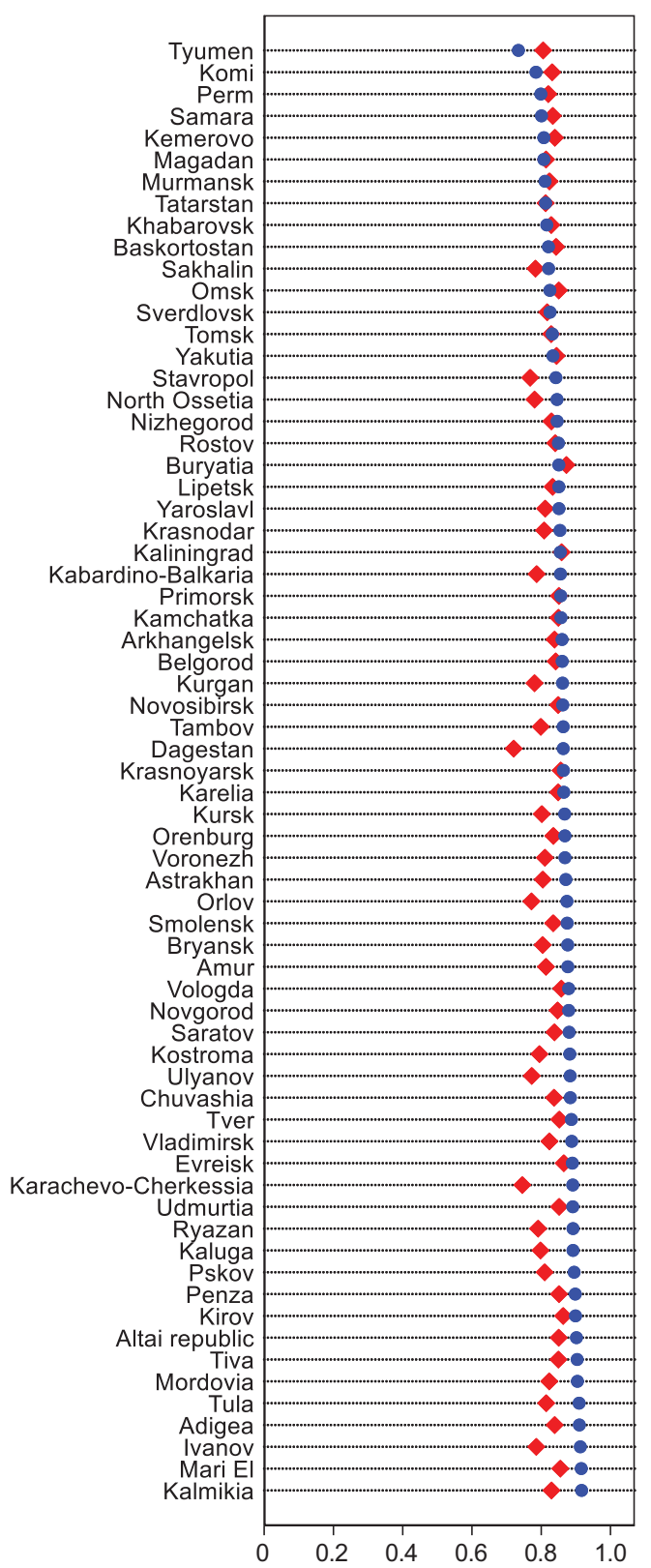

Figure 2. Provincial-level income elasticity of demand for cereal products in 2006 and 2015. Note: Elasticities for 2006 appear in blue, and those for 2015 are in red.

causes of consumer food preference change, given the need for a more sophisticated model, the multitude of potential sources of change along with the likely synergetic effects, and the lack of data that would allow for the estimation of the full-blown model. Finally, the generality of our results may be limited due to the aggregated nature of our data. Future research would significantly benefit from the use of consumer-level household expenditure data such as the one provided by the Russia Longitudinal Monitoring Survey. This would make it possible not only to analyze the welfare consequences of food price increases but also to evaluate the effectiveness of various public policies aimed at mitigating the effects of unfavorable price movements. 
Supplementary material. To view supplementary material for this article, please visit https://doi.org/10.1017/aae.2020.13

Financial support. This work was supported by Wyoming Agricultural Experiment Station funding provided through the USDA National Institute of Food and Agriculture, Hatch project 1016328.

Conflict of interest. None.

\section{References}

Akaike, H. “A New Look at the Statistical Model Identification.” Selected Papers of Hirotugu Akaike. E. Parzen, K. Tanabe, and G. Kitagawa, eds. New York: Springer, 1974.

Alston, J.M., J.A. Chalfant, and N.E. Piggott. "Incorporating Demand Shifters in the Almost Ideal Demand System." Economics Letters 70(2001):73-78.

Attanasio, O., V. Di Maro, V. Lechene, and D. Phillips. "Welfare Consequences of Food Prices Increases: Evidence from Rural Mexico." Journal of Development Economics 104(2013):136-151.

Barsukova, S. 2016. “Why There is Not Enough Milk in Russia?” Internet site: https://iq.hse.ru/en/news/197214680.html (Accessed March 3, 2019)

Bergtold, J., E. Akobundu, and E.B. Peterson. "The Fast Method: Estimating Unconditional Demand Elasticities for Processed Foods in the Presence of Fixed Effects." Journal of Agricultural and Resource Economics 29,2(2004):276-295.

Blanciforti, L.A., R.D. Green, and G.A. King. US Consumer Behavior over the Postwar Period: An Almost Ideal Demand System Analysis. Davis, CA: University of California, Davis, Giannini Foundation Monograph 40, 1986.

Brester, G.W., and T.C. Schroeder. "The Impacts of Brand and Generic Advertising on Meat Demand.” American Journal of Agricultural Economics 77,4(1995):969-979.

Burggraf, C., L. Kuhn, Z. Qi-ran, R. Teuber, and T. Glauben. "Economic Growth and Nutrition Transition: an Empirical Analysis Comparing Demand Elasticities for Foods in China and Russia." Journal of Integrative Agriculture 14,6(2015):1008-1022.

Chalfant, J.A., and J.M. Alston. “Accounting for Changes in Tastes.” The Journal of Political Economy 96,2(1988):391-410.

Chavas, J.P. “Structural Change in the Demand for Meat.” American Journal of Agricultural Economics 65,1(1983):148-153.

Clark, W.A., and K.L. Avery. "The Effects of Data Aggregation in Statistical Analysis." Geographical Analysis 8,4(1976): 428-438.

Cooper, W. Russia's Economic Performance and Policies and Their Implications for the United States. Washington, DC: Congressional Research Service, 2009.

Cramer, J.S. "Efficient Grouping, Regression and Correlation in Engel Curve Analysis." Journal of the American Statistical Association 59,305(1964):233-250.

Dairy Global. “Russian Dairy Sector to Grow Steadily.” Internet site: https://www.dairyglobal.net/Farm-trends/Articles/2019/ 4/Russian-dairy-sector-togrow-steadily-416025E/ (Accessed May 26, 2019).

Deaton, A., and J. Muellbauer. “An Almost Ideal Demand System.” American Economic Review 70(1980):312-326.

Dhar, T., J-P Chavas, and B.W. Gould. "An Empirical Assessment of Endogeneity Issues in Demand Analysis for Differentiated Products.” American Journal of Agricultural Economics 85(2003):605-617.

Dong, F., and F. Fuller. “Dietary Structural Change in China's Cities: Empirical Fact or Urban Legend?" Canadian Journal of Agricultural Economics/Revue canadienne d'agroeconomie 58,1(2010):73-91.

Elsner, K. “Analyzing Russian Food Expenditure Using Micro-Data.” Halle, Germany: Leibniz Institute of Agricultural Development in Central and Eastern Europe (IAMO), Discussion Paper 23, 1999.

FAS/USDA. "Beef \& Pork Consumption in Russia." Beef2Live, 2015. Internet site: http://beef2live.com/story-beef-porkconsumption-russia-0-107035 (Accessed May 26, 2019).

Federal State Statistics Service of Russian Federation (FSSS). Internet site: http://www.gks.ru/wps/wcm/connect/rosstat_ main/rosstat/en/main/ (Accessed December 30, 2016).

Fresh Plaza. "Russia: Increase in Per Capita Consumption of Fruit and Veg.” Fresh Plaza, 2017 Internet site: https://www. freshplaza.com/article/2182777/russia-increase-in-per-capita-consumptionof-fruit-and-veg/ (Accessed May 23, 2019).

Gilbert, C.L. "How to Understand High Food Prices." Journal of Agricultural Economics 61,2(2010):398-425.

Goodwin, B.K. "Multivariate Gradual Switching Systems and the Stability of U.S. Meat Demands: A Bayesian Analysis." Structural Change and Economic Dynamics 3,1(1989):155-166.

Goodwin Jr, H.L., R.B. Holcomb, and R. Shiptsova. "An Evaluation of East Russian Household Expenditures for Non-dairy Animal Protein Sources.” Journal of Food Distribution Research 33(2002):11-20.

Haddad, L. "What Can Food Policy Do to Redirect the Diet Transition?" Washington, DC: International Food Policy Research Institute, Food Consumption and Nutrition Division, Discussion Paper 165, 2003.

Harvard Medical School. "Not All Processed Foods Are Unhealthy." Harvard Men's Health Watch, 2015. Internet site: https://www.health.harvard.edu/staying-healthy/not-all-processed-foods-are-unhealthy (Accessed May 28, 2019). 
Headey, D., and S. Fan. "Anatomy of a Crisis: The Causes and Consequences of Surging Food Prices." Agricultural Economics 39(2008):375-91.

Hovhannisyan, V., and B.W. Gould. "Quantifying the Structure of Food Demand in China: An Econometric Approach." Agricultural Economics 42(2011):1-18.

Hovhannisyan, V., and B.W. Gould. "Structural Change in Urban Chinese Food Preferences." Agricultural Economics 45,2(2014):159-166.

Hovhannisyan, V., and M. Bozic. "Price Endogeneity and Food Demand in Urban China." Journal of Agricultural Economics 68,2(2017):386-406.

Hovhannisyan, V., and H. Khachatryan. "Ornamental Plants in the United States: An Econometric Analysis of a HouseholdLevel Demand System.” Agribusiness 33,2(2017):226-241.

Hovhannisyan, V., and Shanoyan, A. "Addressing Pre-Commitment Bias with a Generalized EASI Model: An Application to Food Demand in Russia." Journal of Agricultural and Resource Economics 44,64(2019):80-97.

Hovhannisyan, V., and S. Devadoss. "Effects of Urbanization on Food Demand in China." Empirical Economics 58(2020):699-721.

International Trade Center (ITC). “International Trade in Goods - Imports 2001-2019.” Internet site: http://www.intracen. org/itc/market-info-tools/statistics-import-country-product/ (Accessed May 28, 2019).

ITEFood\&Drink. "Russia's Baked Goods Sector: Still Strong." ITEFoodeDrink, 2017. Internet site: http://www.foodexhibitions.com/Market-Insights/Russia/Russia-baked-goods-sector-still-strong (Accessed January 21, 2019).

Kearney, J. "Food Consumption Trends and Drivers." Philosophical Transactions of the Royal Society B: Biological Sciences 365,1554(2010):2793-2807.

Lewbel, A., and K. Pendakur. “Tricks with Hicks: The EASI Demand System.” American Economic Review 99(2009):827-863.

Liefert, W.M. "Comparative (Dis?) Advantage in Russian Agriculture." American Journal of Agricultural Economics 84,3(2002):762-767.

Liefert, W.M., and O. Liefert. "Russia's Economic Crisis and Its Agricultural and Food Economy.” Choices 30,1(2015):1-6.

Liefert, W.M., B. Lohmar, and E. Serova. "Transition and Food Consumption.” Paper presented at the Annual Meeting of the International Association of Agricultural Economists, Durban, South Africa, August 16-22, 2003.

Liefert, W., and J. Swinnen. Changes in Agricultural Markets in Transition Economies. Washington, DC: U.S. Department of Agriculture, Economic Research Service, Agricultural Economic Report No. 806, February 2002.

Manig, C., and A. Moneta. "More or Better? Measuring Quality versus Quantity in Food Consumption." Journal of Bioeconomics 16(2014):155-178.

Meatinfo. "Russians Reduced Meat, Fish and Dairy Product Consumption.” Meatinfo, 2020. Internet site: https://meatinfo.ru/ news/rossiyane-sokratili-potreblenie-myasa-ribi-i-molochnih-produktov-367203 (Accessed May 12, 2020).

Menkhaus, D.J., J.S.S. Clair, and S. Hallingbye. "A Re-examination of Consumer Buying Behavior for Beef, Pork, and Chicken.” Western Journal of Agricultural Economics 10,1(1985):116-125.

Moschini, G., and K.D. Meilke. "Modeling the Pattern of Structural Change in US Meat Demand." American Journal of Agricultural Economics 71,2(1989):253-261.

Moschini, G., D. Moro, and R.D. Green. "Maintaining and Testing Separability in Demand Systems." American Journal of Agricultural Economics 76,1(1994):61-73.

Ohtani, K. and S. Katayama. "A Gradual Switching Regression Model with Autocorrelated Errors." Economic Letters 21, 2(1986):169-72.

Okrent, A.M., and J.A. Alston. Demand for Food in the United States. Davis, CA: University of California, Davis, Giannini Foundation Monograph 48, 2011.

Pendakur, K. "EASI Made Easier." Quantifying Consumer Preferences. D. Slottje, ed. Bingley, UK: Emerald Group Publishing Limited, 2009.

Pollak, R.A., and T.J. Wales. "Demographic Variables in Demand Analysis." Econometrica: Journal of the Econometric Society 49,6(1981):1533-1551.

Popkin, B.M., L.S. Adair, and S.W. Ng. "Global Nutrition Transition and the Pandemic of Obesity in Developing Countries." Nutrition Reviews 70,1(2012):3-21.

Ratushnaya, A., and K. Savenkov. "Review of Russian Bread Market." Internet site: http://www.foodmarket.spb.ru/eng/ current.php?article=1197 (Accessed January 20, 2019).

Regmi, A. Changing Structure of Global Food Consumption and Trade: An Introduction. Washington, DC: US Department of Agriculture, Economic Research Service, Market and Trade Economics Division, Agricultural and Trade Report WRS-01-1, 2001.

Rowland, C.S., J.W. Mjelde, and S. Dharmasena. "Policy Implications of Considering Pre-commitments in US Aggregate Energy Demand System.” Energy Policy 102(2017):406-413.

Sachs, J., and W.T. Woo. "Structural Factors in the Economic Reforms of China, Eastern Europe, and the Former Soviet Union.” Economic Policy 9,18(1994):101-145.

Samuelson, P. A. "Some Implications of Linearity." Review of Economic Studies 15(1947-1948):88-90. 
Sharma, R., T. Nguyen, and U. Grote. "Changing Consumption Patterns-Drivers and the Environmental Impact." Sustainability 10,11(2018):4190.

Shiptsova, R., H.R. Goodwin, and R.B. Holcomb. "Household Expenditure Patterns for Carbohydrate Sources in Russia." Journal of Agricultural and Resource Economics 29(2004):296-307.

Staudigel, M. and R. Schröck. "Food Demand in Russia: Heterogeneous Consumer Segments over Time." Journal of Agricultural Economics 66,3(2015):615-639.

Stone, R. "Linear Expenditure Systems and Demand Analysis: An Application to the Pattern of British Demand." The Economic Journal 64(1954):511-527.

Tonsor, G.T., and T.L. Marsh. "Comparing Heterogeneous Consumption in US and Japanese Meat and Fish Demand." Agricultural Economics 37(2007):81-91.

Vorotnikov, V. "Putin Cuts VAT on Breeding Cattle and Poultry in Russia." Global Meat News, 2016. https://www. globalmeatnews.com/Article/2016/07/05/Putin-cuts-VAT-on-breeding-cattle-and-poultry-in-Russia (Accessed May 22, 2019).

Vorotnikov, V. "Russians Are Beginning to Eat More Meat." Global Meat News, 2017. Internet site: https://www. globalmeatnews.com/Article/2017/07/24/Russians-are-beginning-to-eat-more-meat (Accessed May 24, 2019).

Vorotnikov, V. “Export Development Crucial for Poultry Producers.” Poultry World, 2018. Internet site: https://www.poultryworld. net/Meat/Articles/2018/5/Export-development-crucial-for-poultry-producers-284739E/ (Accessed January 19, 2019).

Zhen, C., E.A. Finkelstein, J.M. Nonnemaker, S.A. Karns, and J.E. Todd. "Predicting the Effects of Sugar-Sweetened Beverage Taxes on Food and Beverage Demand in a Large Demand System." American Journal of Agricultural Economics 96,1(2013):1-25.

WorldFood Moscow. “The Russian Food \& Drink Sector: 5 Trends to Watch in 2018.” WorldFood Moscow, 2018a. Internet site: http://www.world-food.ru/en-GB/press/news/Russia-food-drink-trends-2018.aspx (Accessed January 19, 2019).

WorldFood Moscow. "How Green is My Diet? Organic Food in Russia." WorldFood Moscow, 2018b. Internet site: http:// www.world-food.ru/en-GB/press/news/Organic-Food-in-Russia.aspx (Accessed January 21, 2019).

World Trade Organization. World Trade Report 2009: Trade Policy Commitments and Contingency Measures. Geneva: WTO Publications, 2009.

Cite this article: Hovhannisyan V, Kondaridze M, Bastian C, and Shanoyan A (2020). Empirical Evidence of Changing Food Demand and Consumer Preferences in Russia. Journal of Agricultural and Applied Economics 52, 480-501. https://doi.org/ $10.1017 /$ aae.2020.13 